\title{
Soil-atmosphere exchange flux of total gaseous mercury (TGM) at subtropical and temperate forest catchments
}

\author{
Jun Zhou ${ }^{1,2,3,6}$, Zhangwei Wang ${ }^{1,3}$, Xiaoshan Zhang ${ }^{1,3}$, Charles T. Driscoll ${ }^{4}$, and Che-Jen Lin $^{5}$ \\ ${ }^{1}$ State Key Laboratory of Urban and Regional Ecology, Research Center for Eco-Environmental Sciences, \\ Chinese Academy of Sciences, Beijing, 100085, China \\ ${ }^{2}$ Key Laboratory of Soil Environment and Pollution Remediation, Institute of Soil Science, Chinese Academy of Sciences, \\ Nanjing, 210008, China \\ ${ }^{3}$ University of Chinese Academy of Sciences, Beijing, 100049, China \\ ${ }^{4}$ Department of Civil and Environmental Engineering, Syracuse University, Syracuse, \\ New York 13244, USA \\ ${ }^{5}$ Center for Advances in Water and Air Quality, Lamar University, Beaumont, Texas 77710, USA \\ ${ }^{6}$ Department of Environmental, Earth and Atmospheric Sciences, University of Massachusetts Lowell, \\ Lowell, Massachusetts 01854, USA
}

Correspondence: Zhangwei Wang (wangzhw@rcees.ac.cn)

Received: 3 August 2020 - Discussion started: 31 August 2020

Revised: 11 November 2020 - Accepted: 13 November 2020 - Published: 23 December 2020

\begin{abstract}
Evasion from soil is the largest source of mercury $(\mathrm{Hg})$ to the atmosphere from terrestrial ecosystems. To improve our understanding of controls and in estimates of forest soil-atmosphere fluxes of total gaseous $\mathrm{Hg}$ (TGM), measurements were made using dynamic flux chambers (DFCs) over 130 and $96 \mathrm{~d}$ for each of five plots at a subtropical forest and a temperate forest, respectively. At the subtropical forest, the highest net soil $\mathrm{Hg}$ emissions were observed for an open field $\left(24 \pm 33 \mathrm{ng} \mathrm{m}^{-2} \mathrm{~h}^{-1}\right)$, followed by two coniferous forest plots (2.8 \pm 3.9 and $\left.3.5 \pm 4.2 \mathrm{ng} \mathrm{m}^{-2} \mathrm{~h}^{-1}\right)$, a broad-leaved forest plot $(0.18 \pm$ $\left.4.3 \mathrm{ng} \mathrm{m}^{-2} \mathrm{~h}^{-1}\right)$ and the remaining wetland site showing net deposition $\left(-0.80 \pm 5.1 \mathrm{ng} \mathrm{m}^{-2} \mathrm{~h}^{-1}\right)$. At the temperate forest, the highest fluxes and net soil $\mathrm{Hg}$ emissions were observed for a wetland $\left(3.81 \pm 0.52 \mathrm{ng} \mathrm{m}^{-2} \mathrm{~h}^{-1}\right)$ and an open field $\left(1.82 \pm 0.79 \mathrm{ng} \mathrm{m}^{-2} \mathrm{~h}^{-1}\right)$, with lesser emission rates in the deciduous broad-leaved forest $\left(0.68 \pm 1.01 \mathrm{ng} \mathrm{m}^{-2} \mathrm{~h}^{-1}\right)$ and deciduous needle-leaved forest $\left(0.32 \pm 0.96 \mathrm{ng} \mathrm{m}^{-2} \mathrm{~h}^{-1}\right)$ plots, and net deposition at an evergreen pine forest $\left(-0.04 \pm 0.81 \mathrm{ng} \mathrm{m}^{-2} \mathrm{~h}^{-1}\right)$. High solar radiation and temperature during summer resulted in the high $\mathrm{Hg}$ emissions in the subtropical forest and the open field and evergreen pine forest at the temperate forest. At the temperate deciduous plots, the highest $\mathrm{Hg}$ emission occurred in spring during the leaf-off
\end{abstract}

period due to direct solar radiation exposure to soils. Fluxes showed strong positive relationships with solar radiation and soil temperature and negative correlations with ambient air TGM concentration in both the subtropical and temperate forests, with area-weighted compensation points of 6.82 and $3.42 \mathrm{ng} \mathrm{m}^{-3}$, respectively. The values of the compensation points suggest that the atmospheric TGM concentration can play a critical role in limiting TGM emissions from the forest floor. Climate change and land use disturbance may increase the compensation points in both temperate and subtropical forests. Future research should focus on the role of legacy soil $\mathrm{Hg}$ in reemissions to the atmosphere as decreases in primary emissions drive decreases in TGM concentrations and disturbances of climate change and land use.

\section{Introduction}

Mercury ( $\mathrm{Hg})$ is a persistent, bio-accumulative, toxic and well-established global contaminant (Obrist et al., 2018). Unlike other trace metals in the atmosphere, the $\mathrm{Hg}$ mainly exists as the gaseous elemental $\mathrm{Hg}(\mathrm{Hg}(0))$, which accounts for more than $90 \%$ of total gaseous mercury (TGM). $\mathrm{Hg}(0)$ is relatively inert and has a long atmospheric lifetime of 
6 months to 1 year, which allows for long-range transport (Kamp et al., 2018; Slemr et al., 2018; St Louis et al., 2019). Global long-range atmospheric transport and deposition is the main pathway of $\mathrm{Hg}$ input to remote ecosystems (Lin et al., 2019; Ly Sy Phu et al., 2019; Sun et al., 2019). Soils account for more than $90 \%$ of $\mathrm{Hg}$ stored in terrestrial ecosystems (Obrist, 2012), with global topsoil $\mathrm{Hg}$ pools $(0-40 \mathrm{~cm})$ estimated as being $>300000 \mathrm{Mg}$ (Hararuk et al., 2013; Zhou et al., 2017a). The large soil $\mathrm{Hg}$ pools stem not only from geologic sources but also from a legacy of historically anthropogenic emissions over the centuries (Obrist et al., 2014; Du et al., 2019).

Although many studies have focused on primary anthropogenic $\mathrm{Hg}$ emissions, releases from natural source materials are also an important pathway, but with greater uncertainty and variability, which include emissions from natural reservoirs (e.g., volcanic activity, geothermal sources and weathering of $\mathrm{Hg}$ from soil minerals) and re-emissions of previously deposited $\mathrm{Hg}$. These natural sources can be equal to or 2 times larger than anthropogenic sources (Outridge et al., 2018; Fraser et al., 2018). Recent global Hg models estimate that $3600 \mathrm{Mg} \mathrm{yr}^{-1}$ of atmospheric $\mathrm{Hg}$ is deposited to terrestrial surfaces, with $1000 \mathrm{Mg} \mathrm{yr}^{-1}$ being re-emitted back to the atmosphere (Outridge et al., 2018). Moreover, compared to primary anthropogenic emissions of $\mathrm{Hg}\left(2500 \mathrm{Mg} \mathrm{yr}^{-1}\right)$, estimates of re-emissions from soil surfaces are highly uncertain (Outridge et al., 2018; Wang et al., 2018). Compiling data from 132 studies, Agnan et al. (2016) found that the Earth's surface (particularly in East Asia) is an increasingly important source of TGM emissions, with up to half of the global emissions derived from natural sources. They estimated terrestrial TGM emissions of $607 \mathrm{Mg} \mathrm{yr}^{-1}$ but with a large uncertainty range of -513 to $1353 \mathrm{Mg} \mathrm{yr}^{-1}$. Additionally, a recent review suggests that future research should focus on campaigns to understand forest $\mathrm{Hg}$ behavior and long-term $\mathrm{Hg}$ observations, particularly in Asia (Zhang et al., 2019b).

Forest soils receive $\mathrm{Hg}$ inputs from (1) throughfall, including wet deposition plus the wash-off of $\mathrm{Hg}$ (II) deposited on foliage surfaces, (2) litterfall, containing foliage and other plant materials that have assimilated atmospheric $\mathrm{Hg}(0)$, and (3) direct dry $\mathrm{Hg}$ deposition to soil from the atmosphere (Teixeira et al., 2018; Risch et al., 2017; Olson et al., 2018; Cheng et al., 2020). Mercury outputs from forest soils occur from surface or subsurface runoff and air-land surface evasion. Forest soils are highly complex media, with important features that affect soil-air exchange, including soil physiochemical characteristics (e.g., porosity, oxygen availability, redox potential, organic matter and $\mathrm{pH}$; Obrist et al., 2010; Carpi et al., 2014). Other factors also influence this process, such as meteorological conditions (e.g., solar radiation, air temperature and precipitation; Zhou et al., 2015; O'Connor et al., 2019), atmospheric chemistry (ozone, nitrate and hydroxyl radicals; Peleg et al., 2015; Angot et al., 2016), atmospheric TGM concentrations (Wang et al., 2007) and bi- ological processes (Obrist et al., 2010; Chen et al., 2017). Therefore, to characterize and quantify the land-atmosphere exchange of TGM, it is necessary to understand the roles of these factors in mediating this process.

Field studies have shown that elevated anthropogenic $\mathrm{Hg}$ emissions in Southeast Asia have resulted in high atmospheric $\mathrm{Hg}$ concentrations and regional deposition (Kumari et al., 2015; Pan et al., 2010; Zhang et al., 2019b). Forests experience particularly elevated net $\mathrm{Hg}$ loads due to an enhanced deposition associated with the tree canopy, especially in China (Wang et al., 2016; Zhang et al., 2019a). The annual loading of total mercury (THg) to subtropical forests in China has been shown to be much higher than forest catchments in Europe and North America (Wright et al., 2016; Zhou et al., 2020a). High $\mathrm{Hg}$ deposition has resulted in elevated soil $\mathrm{Hg}$ pools in Chinese subtropical forests (Wang et al., 2018; Wang et al., 2009). In contrast, a recent study showed that the $\mathrm{Hg}$ deposition and soil $\mathrm{Hg}$ concentrations at a temperate forest in China were similar to those in Europe and North America (Zhou et al., 2020a). The forested area in China is $2.2 \times 10^{4} \mathrm{~km}^{2}$, with about $50 \%$ and $40 \%$ occurring in subtropical and temperate zones, respectively. Therefore, it seems likely that subtropical and temperate forests in China, with contrasting climate, vegetation cover and atmospheric $\mathrm{Hg}$ deposition, may also show different patterns of Hg cycling.

Forest ecosystems act not only as sinks for atmospheric $\mathrm{Hg}$ deposition but can also serve as sources resulting from legacy $\mathrm{Hg}$ that has accumulated in surface soil. For example, one study constructed the $\mathrm{Hg}$ budget in a subtropical forest in southern China, showing that the forest is a minor sink for atmospheric $\mathrm{Hg}$ but a significant net $\mathrm{Hg}(0)$ source $\left(58.5 \mu \mathrm{g} \mathrm{m}^{-2} \mathrm{yr}^{-1}\right.$; Yu et al., 2020). In contrast, another study, also in southern China, using budgets of airfoliage and air-soil $\mathrm{Hg}(0)$ exchange fluxes, showed that forest is a net sink of $\operatorname{Hg}(0)\left(20.1 \mu \mathrm{g} \mathrm{m}^{-2} \mathrm{yr}^{-1}\right.$; Yuan et al., $2019 a, b)$. These results indicate that there is considerable uncertainty and variability in the source-sink behavior of $\mathrm{Hg}$ in subtropical forests of southern China. Furthermore, no studies have been conducted in northern China to characterize the $\mathrm{Hg}$ fluxes in the temperate forest.

There has been much research characterizing $\mathrm{Hg}$ fluxes between the forest floor and the atmosphere from studies worldwide, as reviewed by Zhu et al. (2016) and Agnan et al. (2016). In this paper, we present measurements on atmosphere-land $\mathrm{Hg}$ fluxes conducted over 130 and $96 \mathrm{~d}$, respectively, during four seasons for five sites, both at a temperate forest catchment at Mount Dongling (MDL) and a subtropical forest catchment at Tieshanping Forest Park (TFP) in China. The aims of this investigation were to (1) characterize the air-land surface $\mathrm{Hg}$ fluxes in different terrestrial ecosystems, (2) conduct detailed field measurements to characterize the uncertainty of land use and climate change in air-surface fluxes of TGM in forest catchments, and (3) compare estimates of $\mathrm{Hg}$ emissions from forest soils at temperate 
and subtropical zones. We hypothesize that a multiplot and multiseasonal study of soil-air fluxes in each forest system will provide new perspectives on climate change and land use on the soil-air Hg fluxes and improve our understanding and estimates of soil $\mathrm{Hg}$ evasion from forest ecosystems.

\section{Materials and methods}

\subsection{Study area}

This study was conducted at TFP in the subtropical zone $\left(106^{\circ} 41.24^{\prime} \mathrm{E}, 29^{\circ} 37.42^{\prime} \mathrm{N}\right)$ and at MDL in the temperate zone $\left(115^{\circ} 26^{\prime} \mathrm{E}, 40^{\circ} 00^{\prime} \mathrm{N}\right)$ in China (Fig. 1). The TFP is dominated by a Masson pine (Pinus massoniana Lamb.) stand (conifer) with some associated species, such as camphor (Cinnamomum camphora) and guger trees (Schima superba Gardner and Champ), which were planted in the 1960s following the loss of a natural Masson pine forest. The forest is located about $20 \mathrm{~km}$ northeast of Chongqing at an altitude from 200 to $550 \mathrm{~m}$. The mean annual precipitation is $1028 \mathrm{~mm}$, with $75 \%$ of the rainfall occurring from May to October. The mean annual air temperature is $18.2^{\circ} \mathrm{C}$. The total area of the study forest in the TFP is $1.06 \times 10^{3}$ ha. The soil is typically mountain yellow earth (corresponding to an Acrisol in the Food and Agriculture Organization (FAO) classification; FAO, 1988), with clay mineralogy dominated by kaolinite (Zhou et al., 2016).

Mount Dongling is near the Beijing Forest Ecosystem Research Station, Chinese Academy of Sciences, which is located $110 \mathrm{~km}$ southwest of the Beijing megacity in northern China. The elevation is $1300 \mathrm{~m}$ above sea level (a.s.l.). The annual average rainfall is $612 \mathrm{~mm}$ and mean relative humidity is $66 \%$. The climate of the region is predominantly warm temperate continent monsoon, with an annual average temperature of $4.8^{\circ} \mathrm{C}$ and precipitation of $611.9 \mathrm{~mm}$. The soil type is mountain brown earth (corresponding to a Eutric cambisol in FAO; FAO, 1988; Zhou et al., 2018). The relatively cool climate in the study area has resulted in deep litter and high organic matter concentrations (Fang et al., 2007). The study area is a mature, secondary forest protected since the 1950s following extensive deforestation. Hg concentrations in the environmental media at the site are provided in the Supplement.

\subsection{Dynamic flux chamber (DFC) measurement}

To reduce the spatial uncertainty in $\mathrm{Hg}$ fluxes, different ecosystems were selected for study in a subcatchment at the subtropical TFP, including a coniferous forest (plots S-A and S-B), a wetland (plot S-C), a broad-leaved (camphor) forest (plot S-D), an open field with bare soil (plot S-E) and a subcatchment at the temperate MDL, including a Chinese pine forest (plot T-A), larch forest (plots T-B), wetland (plots $\mathrm{T}-\mathrm{C}$ ), mixed broad-leaved forest (plots $\mathrm{T}-\mathrm{D}$ ) and open field (plots T-E; Fig. 1). To reduce the temporal uncertainty in $\mathrm{Hg}$ fluxes, 130 and $96 \mathrm{~d}$ of flux observations were undertaken over four seasons (about 1 month of continuous observations for each season, except for 1 week during winter at the MDL; Table S1 in the Supplement). The locations of each plot are described in Table 1 and illustrated in Fig. 1.

Semi-cylindrical quartz glass and open-bottom DFCs $(4.71 \mathrm{~L})$ were utilized during the sampling campaign. The area of the DFCs over the soil surface was $20 \times 30 \mathrm{~cm}$, with six inlet holes ( $1 \mathrm{~cm}$ diameter; Supplement Fig. S1). Local fine-grained soil was placed outside the chamber to seal any gaps between the base of the chamber and the soil. At the outlet of the chamber, an orifice was connected to two exit tubes; one was connected to a regulated suction pump and the other to a gold cartridge for trapping outlet TGM. A substream of air was trapped by a pair of gold quartz cartridges at a flow rate of $0.5 \mathrm{~L} \mathrm{~min}^{-1}$, which was measured using an integrating volume flow meter. All the gold cartridges were constructed with gold silk $(<0.5 \mathrm{~mm}$ diameter). The strands of gold silk were rolled together in a small coil, and about 15 coils were used to fill a quartz cartridge with about $2 \mathrm{~g}$ of gold. The accuracy of all traps was evaluated (see Sect. 2.4), and non-conforming cartridges were discarded. The chamber flushing flow turnover time (TOT) was 0.47 and $0.94 \mathrm{~min}$ for the subtropical forest and temperate forest plots, respectively. The Hg flux was calculated using the following equation:

$F=\left(C_{\mathrm{o}}-C_{\mathrm{i}}\right) \times Q / A$,

where $F$ is the soil $\mathrm{Hg}$ flux $\left(\mathrm{ng} \mathrm{m}^{-2} \mathrm{~h}^{-1}\right) . C_{\mathrm{o}}$ and $C_{\mathrm{i}}$ are the steady-state $\mathrm{Hg}$ concentrations $\left(\mathrm{ng} \mathrm{m}^{-3}\right)$ of the outlet and inlet air streams, respectively, which were calculated by the $\mathrm{Hg}$ mass detected in gold cartridges and the corresponding air volume. $A$ is the surface area enclosed by the DFC. $Q$ is the flow rate of ambient air circulating through the DFC (10 $\mathrm{L} \mathrm{min}^{-1}$ for TFP and $5 \mathrm{~L} \mathrm{~min}^{-1}$ for MDL).

High flow rates and short TOTs are appropriate for measuring flux from soils with high $\mathrm{Hg}$ concentrations or emissions, while lower flow rates and longer TOTs are more appropriate for soils with low $\mathrm{Hg}$ concentrations or emissions. Eckley et al. (2010) suggested that the optimal flow was at the beginning of the stable $C_{\mathrm{o}}-C_{\mathrm{i}}(\Delta C)$ period, which was chosen as a compromise between competing criteria aimed at creating conditions inside the DFC similar to the adjacent outside air. Our previous study showed that when $\Delta C$ was relatively stable, the corresponding flushing flow rate was from 5 to $10 \mathrm{~L} \mathrm{~min}^{-1}$ at the subtropical forest (Zhou et al., 2017a). To avoid the suppression of $\mathrm{Hg}$ emissions due to the excessive buildup of $\mathrm{Hg}$ within the chamber, the flow rate of ambient air circulated through the DFC was $10 \mathrm{~L} \mathrm{~min}^{-1}$ at the subtropical forest. At the temperate forest, the soil $\mathrm{Hg}$ concentrations were about 3-4 times lower than those at the subtropical forest, so the lower flow rate of $5 \mathrm{~L} \mathrm{~min}^{-1}$ was used at these plots. The DFC chambers in all plots were moved every week to mitigate against changes in soil moisture due the covering of soil by the chambers. If a precipitation event occurred, the chambers were also moved to new 


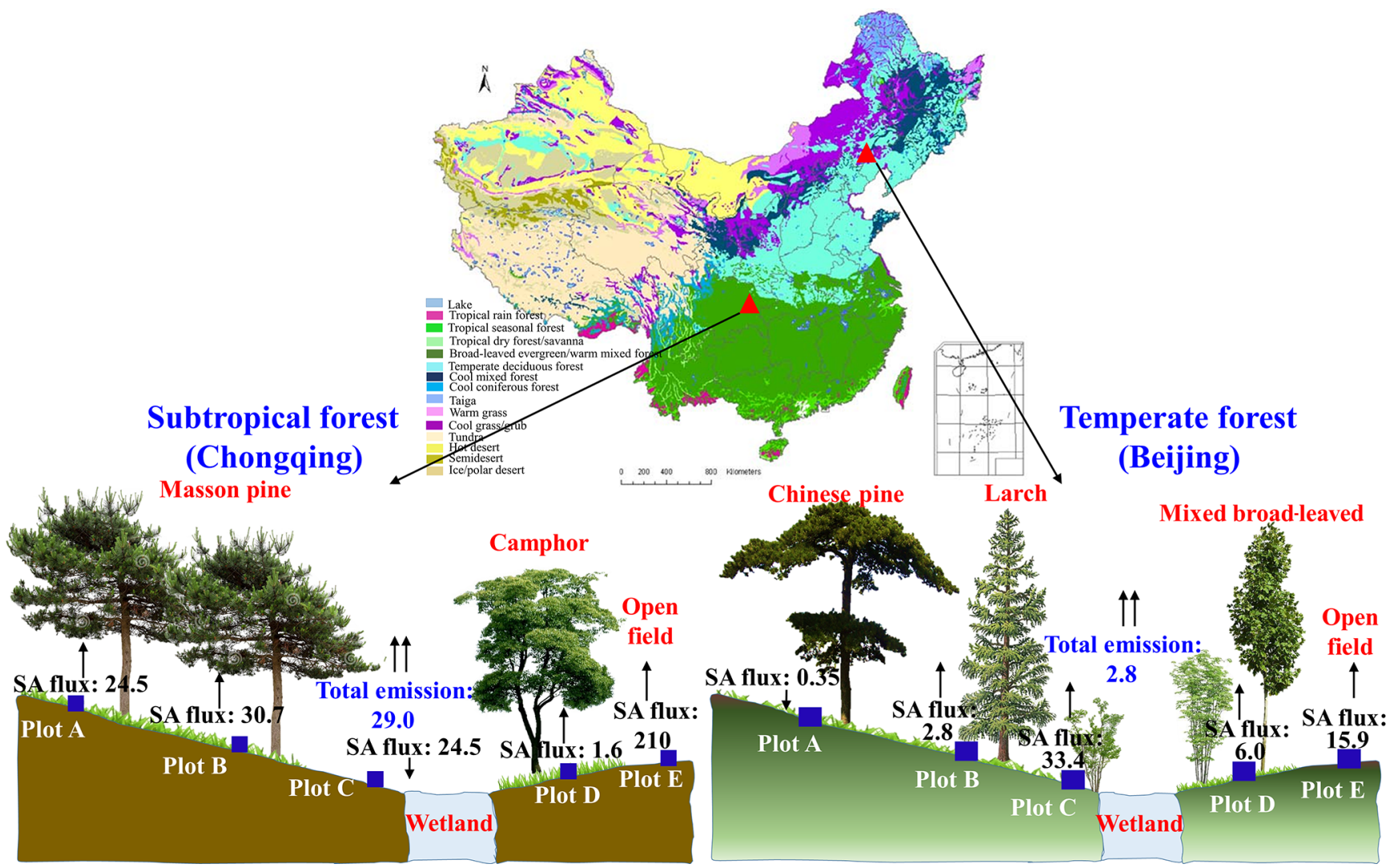

Figure 1. Location of the five sampling plots and the estimation of soil-air (SA) fluxes (values given as $\mathrm{g} \mathrm{m}^{-2} \mathrm{yr}^{-1}$ ) at the temperate and subtropical forest. Potential vegetation of China is from the Vegetation Map of China (Hou, 1982). Up and down arrows represent emission and deposition, respectively.

positions during the sampling period (morning or evening) to be representative of soil conditions receiving ambient precipitation.

The pair of gold cartridges for each DFC was collected twice a day, namely every morning (at about 08:00 local time - LT; hereafter, all times are given in LT and afternoon (about 17:00) representing night (17:00-08:00 of the next day) and day (08:00-17:00) emissions, respectively. A total of 20 gold quartz cartridges were alternated during the sampling program. In addition, diurnal variations in soil-air $\mathrm{Hg}$ fluxes were also conducted in each season, with gold cartridges collected every $30 \mathrm{~min}$. A total of four diurnal measurements were conducted over the study in each forest, with diurnal variations being measured on $1 \mathrm{~d}$ per season. It has been reported that the DFC measurements can introduce bias under a given design, flushing air flow rates and environmental condition (Lin et al., 2010; Zhang et al., 2002). The DFC enclosure imposes a physical constraint that can lead to accumulation in or evasion from the soil surface under measurement. Extensive experiments were conducted at our plot sites to determine the appropriate experimental conditions for accurate measurements. We followed recommendations made by Eckley et al. (2010) for our measurements.

\subsection{Environmental measurements}

At each sampling plot, soil samples were collected from the DFC footprint $(0-5 \mathrm{~cm})$. Soil $\mathrm{Hg}$ and soil organic matter (SOM) concentrations were measured using a DMA-80 direct $\mathrm{Hg}$ analyzer (Milestone Srl, Italy) and loss on ignition (LOI) method, respectively, using methods detailed in the SI. Soil percent moisture and temperature were monitored with a time domain reflectometer (TDR) Hydra Probe II (SDI-12/RS485) and a water cable tester (Stevens Water Monitoring Systems, Inc., USA). Solar radiation was measured by a weather station (Vantage Vue 06250 Wireless Weather Station; Davis Instruments Corporation, USA) located in the TFP Forest Station and Beijing Forest Ecosystem Research Station, within about $500 \mathrm{~m}$ of each plot.

\subsection{Quality assurance and quality control (QA/QC)}

All cartridges were transported to a laboratory at the TFP Forest Station for $\mathrm{Hg}$ determination using a cold vapor atomic fluorescence spectroscopy (CVAFS) detector (Brooks Rand Instruments). The limit of detection, based on 3 times the standard deviation of replicate measurements of the blank was $1 \mathrm{pg}$. Based on the sampled air volume, the detection 


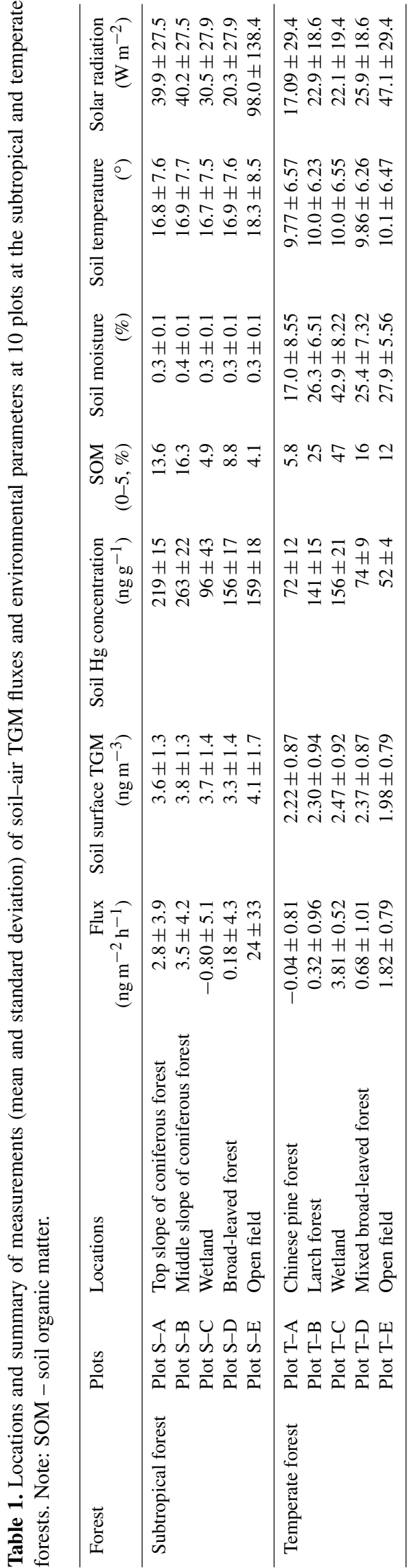

limits were $<0.10 \mathrm{ng} \mathrm{m}^{-3}$. A calibration curve was developed using $\mathrm{Hg}$ saturated air, and the calibration curve was required to have a correlation coefficient greater than 0.99 before the sample analysis could proceed. Before and after the measurement of the sampling cartridges on each day, standard $\mathrm{Hg}$ saturated air was injected to test the accuracy of the $\mathrm{Hg}$ analyzer. If the deviation of the measured $\mathrm{Hg}$ mass was higher than $5 \%$, a new calibration curve would be developed.

A controlled volume of saturated $\mathrm{Hg}$ air at a known temperature was injected to measure the $\mathrm{Hg}$ recovery from the gold cartridges before and after the campaigns in each season. The recoveries of gold cartridges before and after the operation ranged from $98.8 \%$ to $103.2 \%$ and $96.3 \%$ to $102.5 \%$ $(n=155$; average $=98.9 \%)$, respectively. The collection efficiency of $\mathrm{Hg}$ vapor by the gold cartridges was determined by connecting two cartridges in sequence and sampling the ambient air over $24 \mathrm{~h}$ in the laboratory. For all cartridges, less than $1 \% \mathrm{Hg}$ was detected on the second cartridges compared to the first cartridge, indicating that more than $>99 \%$ of the TGM was absorbed by the gold cartridges during the field operation. For comparison, $\mathrm{Hg}$ fluxes were measured by two side-by-side chambers simultaneously. Blanks of the soil TGM flux sampling systems were measured by placing the DFC on a quartz glass surface in the five plots. The sampling time for the blank measurements was the same as the soilair TGM flux measurements, which were collected at 08:00 and 17:00, representing night (17:00-08:00 of the next day) and day (08:00-17:00) emissions, respectively. The averaged blank was $0.13 \pm 0.21 \mathrm{ng} \mathrm{m}^{-2} \mathrm{~h}^{-1}(n=10)$, which was subtracted from the soil-air TGM flux for each season.

\subsection{Statistical analysis}

Structural equation modeling (SEM) was performed on the collected $\mathrm{Hg}$ flux data using Amos software. SEM, developed from a fully conceptual model using $\chi 2$ tests with maximum likelihood estimation, was conducted to infer the interplay of temperature, solar radiation, soil moisture and air TGM concentrations on measurements of soil-air TGM exchange fluxes. Seasonal and annual fluxes were compared among the 10 plots. Separate two-way analyses of variance (ANOVA) were used to determine if differences in $\mathrm{Hg}$ fluxes existed among the seasons and sites. All differences in mean values were significant at the $p=0.05$ level, and all means are reported with \pm 1 standard deviation from the mean. The correlations between environmental parameters and fluxes were analyzed by Pearson's correlation tests, using SPSS statistics software (SPSS Inc., 16.0), and correlation coefficient and $p$ values are presented and significantly correlated at the level of 0.05 . 


\section{Results and discussion}

\subsection{Landscape and forest species dependence on soil-air Hg fluxes at the forest catchment scale}

The soil TGM flux measurements for the five plots were calculated for the day and night and reported as mean daily fluxes with standard deviations (SDs) at the subtropical (Fig. 2a) and temperate forests (Fig. 2b). Over the course of the campaigns, net TGM emission was observed at the open field $\left(24 \pm 33 \mathrm{ng} \mathrm{m}^{-2} \mathrm{~h}^{-1}\right)$, coniferous forest (upper elevation $2.8 \pm 3.9 \mathrm{ng} \mathrm{m}^{-2} \mathrm{~h}^{-1}$, mid elevation $\left.3.5 \pm 4.2 \mathrm{ng} \mathrm{m}^{-2} \mathrm{~h}^{-1}\right)$ and the broad-leaved forest $(0.18 \pm$ $4.3 \mathrm{ng} \mathrm{m}^{-2} \mathrm{~h}^{-1}$ ), while net deposition was evident at the wetland $\left(-0.80 \pm 5.1 \mathrm{ng} \mathrm{m}^{-2} \mathrm{~h}^{-1}\right)$, respectively, at the subtropical forest. At the temperate forest, net TGM emission was observed at the wetland $\left(3.81 \pm 0.52 \mathrm{ng} \mathrm{m}^{-2} \mathrm{~h}^{-1}\right)$, open field $\left(1.82 \pm 0.79 \mathrm{ng} \mathrm{m}^{-2} \mathrm{~h}^{-1}\right)$, mixed broadleaved forest $\left(0.68 \pm 1.01 \mathrm{ng} \mathrm{m}^{-2} \mathrm{~h}^{-1}\right)$ and larch forest $\left(0.32 \pm 0.96 \mathrm{ng} \mathrm{m}^{-2} \mathrm{~h}^{-1}\right)$, while net deposition was evident at the Chinese pine forest $\left(-0.04 \pm 0.81 \mathrm{ng} \mathrm{m}^{-2} \mathrm{~h}^{-1}\right)$, respectively. The fluxes at the temperate forest were 10 times lower than values at the subtropical forest due to different environmental factors, such as lower temperature, solar radiation and soil $\mathrm{Hg}$ concentrations (see Sect. 3.3).

These patterns suggest that soil-air $\mathrm{Hg}$ fluxes at the catchment scale vary according to soil properties (e.g., soil $\mathrm{Hg}$ concentration, moisture and soil organic matter - SOM) and forest species composition. High variability, as evidenced by high SD and coefficient of variation (SD/mean, with a range of $14 \%-2374 \%$ ), was evident in the daily $\mathrm{Hg}$ fluxes largely driven by meteorological variation. The fluxes at the subtropical forest plots of this study were much lower than those reported for other subtropical evergreen forests in China, such as Mount Gongga (0.5-9.3 $\mathrm{ng} \mathrm{m}^{-2} \mathrm{~h}^{-1}$ ) (Fu et al., 2008), Mount Jinyun (14.2 $\mathrm{ng} \mathrm{m}^{-2} \mathrm{~h}^{-1}$; Ma et al., 2013) and Mount Simian (11.23 $\mathrm{ng} \mathrm{m}^{-2} \mathrm{~h}^{-1}$; Ma et al., 2018), all of which were generally conducted during sunny days. Our flux measurements at the temperate forest were slightly lower or comparable to those in North American deciduous forests, ranging from -0.73 to $2.7 \mathrm{ng} \mathrm{m}^{-2} \mathrm{~h}^{-1}$ (Choi and Holsen, 2009b; Hartman et al., 2009; Carpi et al., 2014; Ma et al., 2018). These results demonstrated that measurements over several days may exhibit considerable temporal variability, and a long-term study should be undertaken to reduce the uncertainty in temporal patterns of soil $\mathrm{Hg}$ emissions.

The mean TGM fluxes in the open fields were about 10 and 6 times higher than those under the forest canopy at the subtropical and temperate forests, respectively $(p<0.001)$. Our results are consistent with those of Ma et al. (2013) and Xin and Gustin (2007), which show large Hg evasion following forest conversion to bare soils, due to direct exposure to sunlight, as fluxes were enhanced by increases in solar radiation and temperature. Due to frequent heavy rains at the subtropical forest catchment, a large amount of sur- face runoff impacted the wetland (plot S-C). Elevated runoff may have decreased $\mathrm{Hg}\left(96 \pm 43 \mathrm{ng} \mathrm{g}^{-1}\right)$ and SOM in surface soils due to erosion (Table 1). This site had the lowest TGM fluxes of the plots studied at the subtropical forest (overall net sink). In addition, soils in the wetland plot were mostly saturated throughout the year, limiting $\mathrm{Hg}$ fluxes and likely contributing to the sink behavior. In contrast, the mean annual rainfall was $40 \%$ lower at the temperate forest, and the wetland was located at relatively lower terrain. Litter from surrounding higher terrain forest accumulated in the low-lying wetland. The cool and dry climate also contributed to high organic matter and low bulk density (Fang et al., 2007). Higher SOM likely facilitated the binding of trace metals, leading to high soil $\mathrm{Hg}$ concentrations (117 $\mathrm{ng} \mathrm{g}^{-1}$ ) at the temperate wetland. These conditions were conducive to biological activity, promoting the mineralization of SOM and the release of volatile $\mathrm{Hg}(0)$ from the soil (Choi and Holsen, 2009b; Osterwalder et al., 2019). The wetland had the highest TGM fluxes of the plots studied at the temperate forest (overall net source). Previous studies have suggested that soil water is able to mobilize $\mathrm{Hg}$ from binding sites on the soil (Gustin, 2003; Kocman and Horvat, 2010) and high soil water decreases soil redox potential (Zarate-Valdez et al., 2006), both of which can facilitate the conversion of $\mathrm{Hg}(\mathrm{II})$ to $\mathrm{Hg}(0)$. Additionally, the climate is relatively dry in northern China, especially in spring. The high solar radiation and relatively high air temperature enhance not only the reduction of $\mathrm{Hg}(\mathrm{II})$ to $\mathrm{Hg}(0)$ but also increase water evaporation compared to other study sites. Enhanced water evaporation at a higher temperature facilitates $\mathrm{Hg}$ emissions from soils (Gustin and Stamenkovic, 2005; Lin et al., 2010). Additionally, given that $\mathrm{Hg}$ conversion to $\mathrm{Hg}(0)$ in soil profiles occurs mainly via biotic processes, maximum aerobic microbial activity has been delineated at a soil water content equivalent to $60 \%$ of a soil's water-holding capacity (Breuer et al., 2002; Kiese and Butterbach-Bahl, 2002). Appropriate soil moisture in the wetland would likely enhance the microbial reduction of $\mathrm{Hg}(\mathrm{II})$ to $\mathrm{Hg}(0)$. Therefore, the highest $\mathrm{Hg}$ flux was observed in the temperate wetland, especially in spring. The main reasons for the significant differences between the soil $\mathrm{Hg}$ fluxes at the two wetland sites are likely that the saturated soil at the subtropical forest inhibited $\mathrm{Hg}(0)$ evasion (Gustin and Stamenkovic, 2005; see Sect. 3.3).

At the subtropical forest, litterfall in the broad-leaved (camphor) plot (plot S-D) was twice as high as that of the coniferous (pine) plot (plots S-A and S-B; Zhou et al., 2018), likely resulting in greater shielding of sunlight to the surface soil and limiting soil $\mathrm{Hg}$ evasion. Increases in light transmission through the canopy increase both solar radiation and soil temperature, which can enhance the photochemical reduction of $\mathrm{Hg}$ (II) at the soil surface and $\mathrm{Hg}(0)$ evasion. In the mid-slope of the pine stand (plot S-B), soil Hg concentration was elevated compared to the upslope plot (Table 1), with correspondingly higher soil $\mathrm{Hg}$ fluxes. At the temperate forest, the lowest $\mathrm{Hg}$ flux and overall deposition 

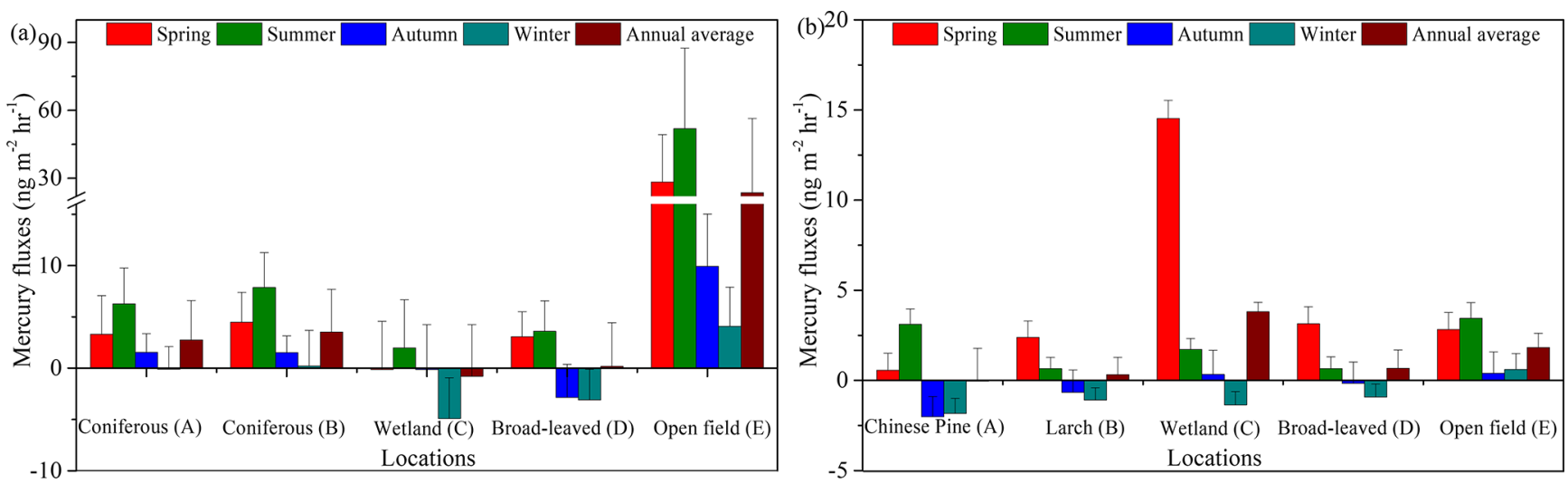

Figure 2. Mean and standard deviations of soil-air TGM fluxes at the five plots for the four seasons and annual values during the study at the subtropical forest (a) and temperate forest (b). The number of flux observations in spring, summer, autumn and winter were 62, 92, 66 and 43 at the subtropical forest and 60, 58, 60 and 14 for the temperate forest, respectively.

was observed at the evergreen forest of Chinese pine, where the canopy cover likely limited $\mathrm{Hg}$ flux by decreasing solar radiation to soil and warming. Similarly, at the subtropical forest, the needle biomass in the larch plot was about 2.5 times greater as that in the mixed broad-leaved plot (plot $\mathrm{T}-$ D) at the temperate forest, resulting in shielding of the sunlight to the surface soil and limiting soil $\mathrm{Hg}$ evasion at the larch plot.

The forest canopy influences not only the soil $\mathrm{Hg}$ concentration by mediating the atmospheric $\mathrm{Hg}$ deposition (Zhou et al., 2017a, 2018) but also alters soil physiochemical properties (e.g., SOM, pH and porosity; Mo et al., 2011) and microbial communities (Nagati et al., 2020), which in turn affects soil-air exchange. For example, the annual litterfall $\mathrm{Hg}$ deposition flux at the broad-leaved plot $\left(91 \mu \mathrm{g} \mathrm{m}^{-2} \mathrm{yr}^{-1}\right)$ at the subtropical forest was approximately 2 times greater than the coniferous plot $\left(41 \mathrm{~g} \mathrm{~m}^{-2} \mathrm{yr}^{-1}\right.$; Zhou et al., 2018). Conversely, the SOM and soil $\mathrm{Hg}$ concentrations in the broadleaved forest were lower than the coniferous forest. Moreover, the litter decomposition rate was lower, but the Hg mass accumulation in the litter was much higher in the coniferous forest compared to the broad-leaved forest due to higher throughfall $\mathrm{Hg}$ deposition at the coniferous plot (Zhou et al., 2018), which resulted in a seemingly inconsistent pattern between litterfall mass and SOM and litterfall Hg deposition and soil $\mathrm{Hg}$ concentrations. At the temperate forest, the higher litterfall $\mathrm{Hg}$ deposition and lower litter decomposition in the larch plot compared to the broad-leaved plot (Zhou et al., 2017a) resulted in significantly higher SOM and soil Hg concentrations (Table 1). Tree species can change the physicochemical properties of soil (e.g., SOM and soil Hg concentrations) and influence soil-air exchange. These biological factors likely contribute to the much lower TGM evasion in the broad-leaved plot than the coniferous plot at the subtropical forest but much higher TGM evasion in the broad-leaved plot than the deciduous needle (larch) plot at the temperate forest (Fig. 2).

Most studies measure soil TGM fluxes at only one location or at a single forest stand to characterize the whole ecosystem. Our observations clearly show that soil-air $\mathrm{Hg}$ fluxes vary substantially across different plots (Fig. 2), indicating that forest type/cover and landscape position significantly affect the TGM fluxes, and therefore, the spatial variability in soil $\mathrm{Hg}$ fluxes among different subplots must be considered. Based on the areal distribution of each plot type in the study subcatchments of the subtropical forest (coniferous upland and mid-slope, broad-leaved, wetland and open; $4.6 \mathrm{ha}$ ) and the temperate forest (Chinese pine, larch, wetland, mixed broad-leaved and open; 5.0 ha; Table S1), the area-weighted TGM flux was 3.2 and $0.32 \mathrm{ng} \mathrm{m}^{-2} \mathrm{~h}^{-1}$ for the entire subtropical and temperate catchments, respectively. The areaweighted TGM fluxes were $14 \%$ higher than plot S-A and $16 \%$ lower than plot S-B of the Masson pine stand at the subtropical forest and were $907 \%$ higher than Chinese pine plot and 53\% lower than mixed broad-leaved plot at the temperate forest, respectively. The observations at several plots with diverse forest cover in this study should reduce the overall uncertainty associated with soil-air fluxes of TGM in the overall forest catchment.

\subsection{Seasonal variations in soil-air $\mathrm{Hg}$ fluxes at the forest catchment scale}

Soil TGM fluxes exhibited not only clear seasonal variations at all the plots but were also responsive to phenological and meteorological patterns. At the subtropical forest, soil $\mathrm{Hg}$ fluxes were generally the highest in the summer (Fig. 2a), which showed net emissions at all the five plots, followed by spring and autumn, with the lowest values during winter, which exhibited net deposition at all plots, with the exception of plot $\mathrm{S}-\mathrm{B}$. The observed seasonal variation was dependent on sunlight (Fig. 3) because solar radiation 
drives the photochemical reduction of $\mathrm{Hg}$ (II) (note the correlation between the TGM fluxes and solar radiation; Fig. S2). Additionally, greater solar radiation increases temperature, which promotes the production of soil $\mathrm{Hg}$ gas by biological and abiotic processes. At the temperate forest, the $\mathrm{Hg}$ fluxes were the highest in the deciduous forest plot (wetland, mixed broad-leaved forest and larch forest) in spring, before leaf-out, when solar radiation could directly reach the forest floor (Fig. S3). In the open field and evergreen forest (Chinese pine forest) plots, the $\mathrm{Hg}$ fluxes were highest in summer, with the highest solar radiation and temperature (Figs. 4 and $\mathrm{S} 3$ ). The lowest $\mathrm{Hg}$ fluxes were measured in the winter at all plots when the soil was covered with snow, with net Hg emission observed at the open field and net deposition observed at the other four sites (Fig. 2b).

We also observed strong variations in TGM evasion under different weather conditions. Rain events decreased TGM fluxes at all plots in both forests (Fig. S4) as the rainwater decreased soil pore space, leading to decreases in evasion from the soil. Furthermore, the solar radiation and temperature during rainy days was much lower than those for sunny days for a given season (Figs. 3 and 4). Manca et al. (2013) studied snow-air $\mathrm{Hg}$ exchange at $\mathrm{Ny}$-Ålesund, showing on average a small net deposition $-0.24 \mathrm{ng} \mathrm{m}^{-2} \mathrm{~h}^{-1}$. Likewise, overall deposition between -0.6 and $-23.8 \mathrm{ng} \mathrm{m}^{-2} \mathrm{~h}^{-1}$ was observed at snow-covered agricultural areas in northeastern China (Wang et al., 2013; Zhang et al., 2013). However, some studies of snowpack have shown net $\mathrm{Hg}$ deposition at nighttime and net emissions during daytime due to high solar radiation (Maxwell et al., 2013; Spolaor et al., 2019). Empirical models suggest that most of the $\operatorname{Hg}(0)$ deposited to snow was re-emitted back to the atmosphere (Durnford and Dastoor, 2011). During the campaigns in winter, the solar radiation was relatively lower, which may be why net deposition occurred (Fig. 4). Additionally, refrozen ice/snow layers are characterized by elevated $\mathrm{Hg}$ concentrations, and the deposited $\mathrm{Hg}$ from atmosphere could be potentially released to meltwater (Zhang et al., 2012; Perez-Rodriguez et al., 2019), which is consistent with our results that atmospheric $\mathrm{Hg}$ deposition could be released to meltwater during snow melt. Our observations through the annual climatic cycle reduce the uncertainty and bias of temporal patterns of soil-air $\mathrm{Hg}$ fluxes. Moreover, multiplot observations reduce the uncertainty and bias associated with spatial variation. Together, these more detailed measurements improved estimates of overall ecosystem soil $\mathrm{Hg}$ evasion and confirm our hypothesis.

\subsection{Correlations between environmental factors and fluxes}

To investigate the correlation between soil-atmosphere fluxes and environmental factors, data over the four seasons were used. These data offer a long, continuous time series for the five measurement plots in each forest (Figs. 3 and
4). According to a global database, atmospheric fluxes at $\mathrm{Hg}$-enriched sites are positively correlated with substrate $\mathrm{Hg}$ concentrations, but this relationship is not observed at sites with lower background concentrations of soil $\mathrm{Hg}$ (Agnan et al., 2016). Our soil $\mathrm{Hg}$ fluxes were strongly correlated with soil $\mathrm{Hg}$ concentrations at vegetated sites (forests and wetland) at the subtropical forest (Fig. S5) but not at the temperate forest.

Photo-reduction is a major driver of TGM evasion from the Earth's surface (Howard and Edwards, 2018; Kuss et al., 2018; Gao et al., 2020). This process is due to a photochemically mediated reduction that converts soil water $\mathrm{Hg}$ (II) to volatile $\mathrm{Hg}(0)$ and enhances the $\mathrm{Hg}(0)$ pool in soil pores (Xin and Gustin, 2007; Choi and Holsen, 2009a). Therefore, the elevated soil pore $\operatorname{Hg}(0)$ concentrations increased the potential for TGM diffusion from the soil to the atmosphere, which drives an increase of $\mathrm{Hg}$ emissions from soil. At all the study sites, no matter the daily average fluxes (Figs. 3 and 4), daytime fluxes (Figs. S2 and S3) were all significantly correlated with solar radiation, and the solar radiation also increased daytime fluxes compared to nighttime values (Fig. S6). In the evergreen plots of the subtropical (plots S-A, S-B and $\mathrm{S}-\mathrm{D}$ ) and temperate (plot $\mathrm{T}-\mathrm{A}$ ) forests, $\mathrm{Hg}$ fluxes were the most highly dependent on soil temperature compared to the solar radiation during the four seasons, likely due to evergreen canopy limiting solar radiation to the forest floor. With the consistent shade of the coniferous forest canopy, the $\mathrm{Hg}$ flux was highly dependent on soil surface temperature rather than solar radiation to the forest floor.

To consider the synergistic effects from multiple factors, SEM was applied to infer the soil-air TGM exchange processes (Fig. 5). It is clear that temperature was a more dominant factor driving the air-soil TGM exchange flux over the four seasons in the subtropical forest plots, while solar radiation was a more dominant factor at the temperate forest due to direct exposure of the forest floor to solar radiation the leaf-off seasons. At the open fields of both forests, temperature and solar radiation had a synergistic effect on soil $\mathrm{Hg}$ fluxes. A recent study of soil-air TGM fluxes at a subtropical evergreen broadleaf forest in southern China also suggested that temperature is the most important driver of air-soil TGM exchange (Yuan et al., 2019b). Therefore, we may infer that, under the shade of the forest canopy, temperature is the dominant factor causing variation in TGM evasion from forest soil.

Mercury fluxes in wetlands in both forests (plots S-C and $\mathrm{T}-\mathrm{C}$ ) were less strongly correlated with soil temperature compared to the other plots in both forests (Figs. S7 and S8). Generally, temperature is an important factor that promotes TGM evasion after its formation from $\mathrm{Hg}(\mathrm{II})$, more by biotic than abiotic processes in soils (Pannu et al., 2014). $\mathrm{The} \operatorname{Hg}(0)$ in soil pore gas mainly results from biotic production. For example, soil sterilization can decrease the $\mathrm{Hg}$ converted to $\operatorname{Hg}(0)$ by $\sim 50 \%$; additionally, $1 \%$ of the soil $\mathrm{Hg}$ is converted to $\mathrm{Hg}(0)$ via abiotic processes, compared to 

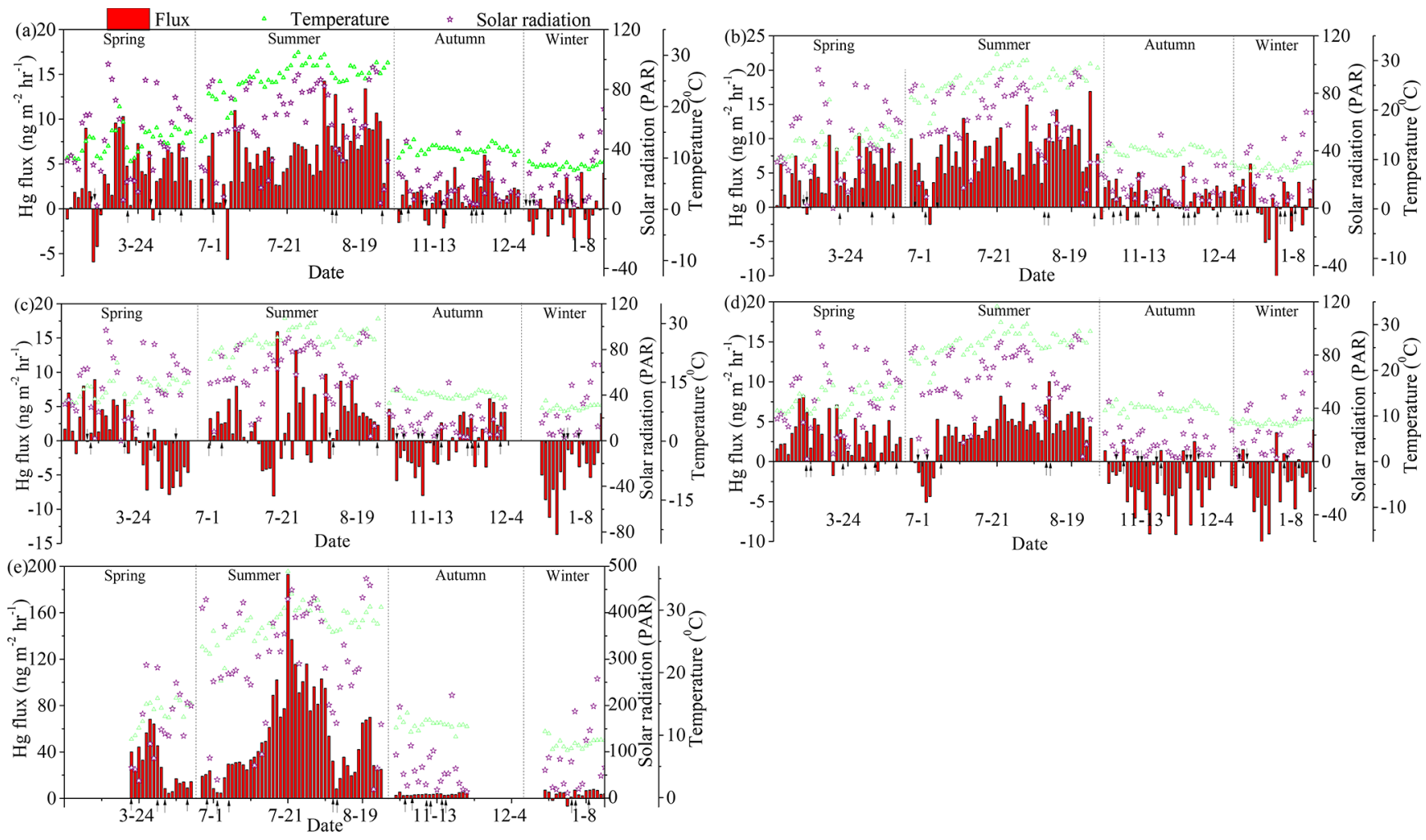

Figure 3. Daily (average flux of day and night) composite $\mathrm{Hg}$ flux, solar radiation and soil temperature at a Masson pine forest (a, b) and wetland (c), evergreen broad-leaved forest (d) and open field (e) plots in a subtropical forest. The vertical arrows represent precipitation events.

$6.8 \%$ by biotic processes at $283 \mathrm{~K}$, and the fraction of $\mathrm{Hg}$ reduction by biotic processes increases with temperature increases (Pannu et al., 2014). At the subtropical forest, the wetland soil was largely saturated. This condition likely limited the soil pore release of TGM to the atmosphere, resulting in a weaker correlation between soil temperature and $\mathrm{Hg}$ fluxes. Furthermore, the $\mathrm{Hg}$ exchange fluxes were more dependent on solar radiation and less dependent on temperature during the leaf-off period at the temperate deciduous plots; therefore, the $\mathrm{Hg}$ fluxes were more solar-radiation driven in the deciduous forests, especially in the wetland (Figs. S3 and S7).

During the campaign, significant negative correlations were evident between the soil moisture and soil-air fluxes of TGM at the five plots at the subtropical forest $\left(r^{2}=0.03-\right.$ $0.39 ; p<0.05$ for all; Fig. S9), but there was no significant correlation with soil moisture for the temperate forest (Fig. S10). Generally, there is an optimum soil moisture condition that maximizes soil TGM flux (Gustin and Stamenkovic, 2005; Lin et al., 2010; Obrist et al., 2014; Osterwalder et al., 2018; Johnson et al., 2003), which ranges from $60 \%$ to $80 \%$ of the water-holding capacity of a soil (Pannu et al., 2014). A laboratory experiment using undisturbed soil collected from the our subtropical study area showed that increasing soil moisture from $2 \%$ to $20 \%$ in- creased the TGM flux to $80 \%$ at $24^{\circ} \mathrm{C}$ (Wang et al., 2014). A second field experiment was conducted to study the effects of higher soil moisture on TGM flux at the subtropical forest, showing that increasing soil moisture gradually decreased the soil $\mathrm{Hg}$ emissions over the range of 31\%-39\% (Zhou et al., 2017b). Combining the results of these experiments, the soil $\mathrm{Hg}$ fluxes at the subtropical forest catchment appear to increase from low values of soil moisture, reaching an optimum in the range of $20 \%-30 \%$, and then decreasing with increasing soil moisture above these values. In the current study, we observed that following an extended dry period with an extended wet period enhanced the Hg fluxes in both forests; however, individual rainfall events did not enhance or decrease the $\mathrm{Hg}$ fluxes due to short-term increases in soil moisture and lower solar radiation associated with those events (Figs. 3 and 4). Additionally, Lin et al. (2010) observed the synergistic effects $(20 \%-30 \%$ of an additional flux enhancement) between air temperature $\left(15\right.$ and $\left.30^{\circ} \mathrm{C}\right)$ and soil moisture $(2.5 \%$ and $27.5 \%)$. Perennially humid weather results in relatively high soil moisture at the subtropical forest (largely $>25 \%$ during the campaigns). Considering the relatively high bulk density and low porosity of soil at the subtropical forest (Sørbotten, 2011), soil moisture likely exceeded the optimum range for TGM evasion during the campaigns, resulting in significantly negative correla- 

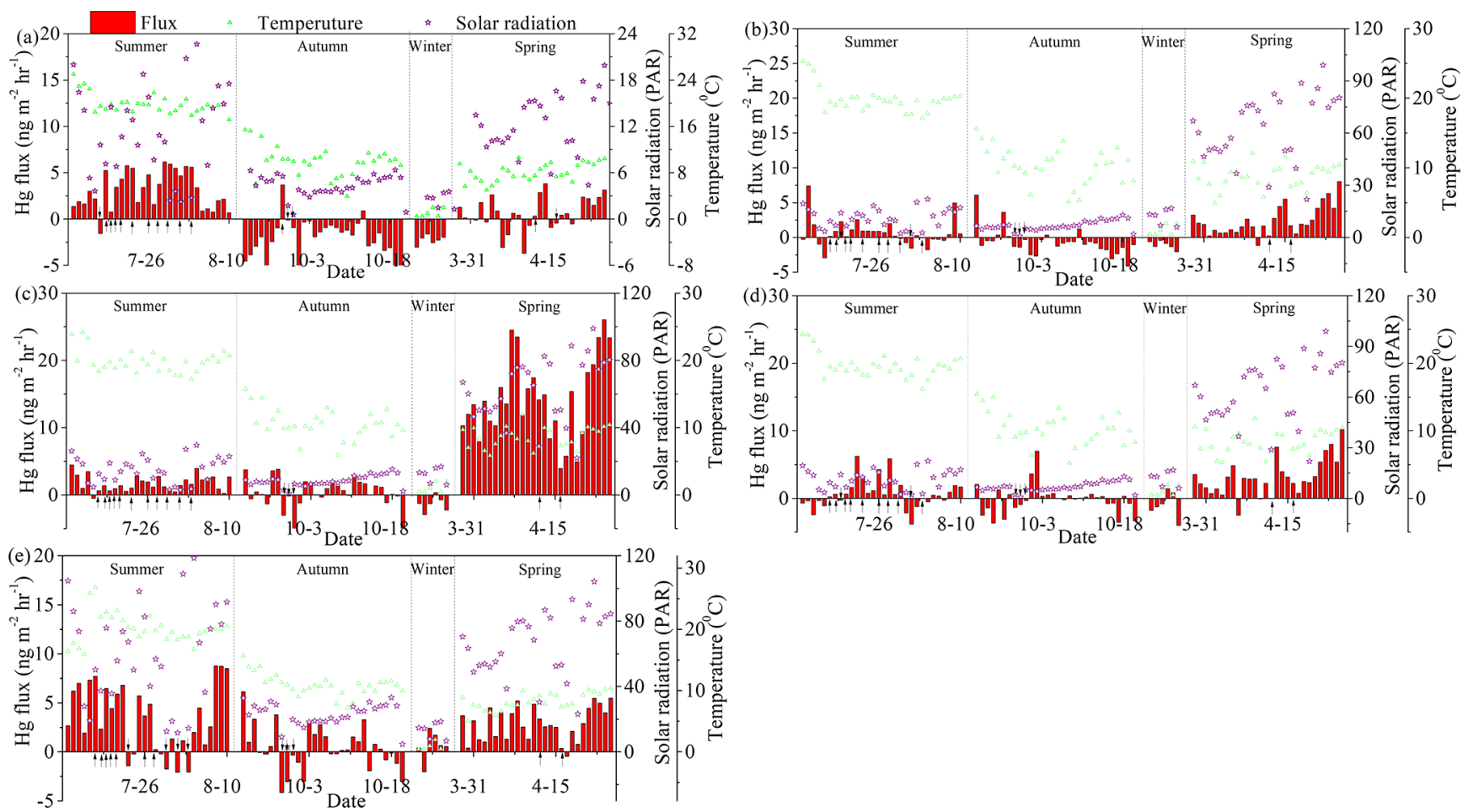

Figure 4. Daily (average flux of day and night) composite $\mathrm{Hg}$ flux, solar radiation and soil temperature at a Chinese pine forest (a), larch forest (b), wetland (c), mixed broad-leaved forest (d) and open field (e) plots in a temperate forest. The vertical arrows represent precipitation events.

tions (Fig. S9). In contrast, lower bulk density and higher soil porosity would result in a higher optimum range of soil moisture at the temperate forest. Moreover, the temperate forest had a large range of soil moisture (2\% to $60 \%)$ in the five plots which, when combined with the synergistic effects of soil moisture with temperature (Lin et al., 2010), resulted in a condition in which moisture was not a main driver of TGM evasion.

Soil-air Hg fluxes also showed significant negative correlations with atmospheric TGM concentrations at the 10 plots at both forests $\left(r^{2}=0.023-0.26, p<0.05\right.$, Figs. 6 and 7$)$, which had a greater effect than soil moisture at both forests, except for plots T-C, S-A and S-E (Fig. 5). According to the two-resistance exchange interface model, the exchange fluxes of $\mathrm{Hg}$ are controlled by the gradient of TGM concentrations at both interfaces (Zhang et al., 2002). As a result, elevated atmospheric TGM concentrations should decrease the diffusion of soil pore TGM to the atmosphere. In a companion study, the soil pore TGM concentrations were measured at all the plots at the subtropical and temperate forests, except the wetlands (Zhou et al., 2020b). These results showed that gradient of TGM concentrations between the surface air and pore air at $3 \mathrm{~cm}$ were significantly correlated with the soilair TGM fluxes at all the plots (Figs. S11 and S12). These results are consistent with an experiment conducted at this subtropical forest, where artificially increasing ambient air TGM concentrations significantly inhibited soil $\mathrm{Hg}$ volatilization (Zhou et al., 2017b). SEM inferred that air TGM concentrations was the second important driver influencing the soil-air TGM exchange in Masson pine (Plot S-B), evergreen broadleaved and wetland plots at the subtropical forest (Fig. 5).

Xin and Gustin (2007) and Gustin et al. (2006) defined an associated concept of the compensation point for soils, which is the atmospheric $\mathrm{Hg}$ concentration at which the net $\mathrm{Hg}$ flux between the soil and the atmosphere is zero. If the atmospheric TGM concentration is above the compensation point, atmospheric deposition occurs; if the concentration is below the compensation point, soil emission occurs. The strong linear relationships are shown in Figs. 5 and $6(p<0.01)$, resulting in compensation points of 2.47, 2.97, 6.00, 3.33 and $3.50 \mathrm{n} \mathrm{m} \mathrm{m}^{-3}$ for Chinese pine, larch, wetland, mixed broadleaved forests and open field at the temperate forest, with an area-weighted compensation point of $3.42 \mathrm{ng} \mathrm{m}^{-3}$. The compensation points were much higher at the subtropical forest, with values of $6.50,7.71,3.92,3.83$ and $12.91 \mathrm{ng} \mathrm{m}^{-3}$ for Masson pine upland and mid-slope, wetland, broadleaved and open field at the subtropical forest, with an areaweighted compensation point of $6.82 \mathrm{ng} \mathrm{m}^{-3}$. Another study of subtropical coniferous forest showed similar compensation points $\left(7.75 \mathrm{ng} \mathrm{m}^{-3}\right)$ to those in the Masson pine forests of our study (Luo, 2015). 

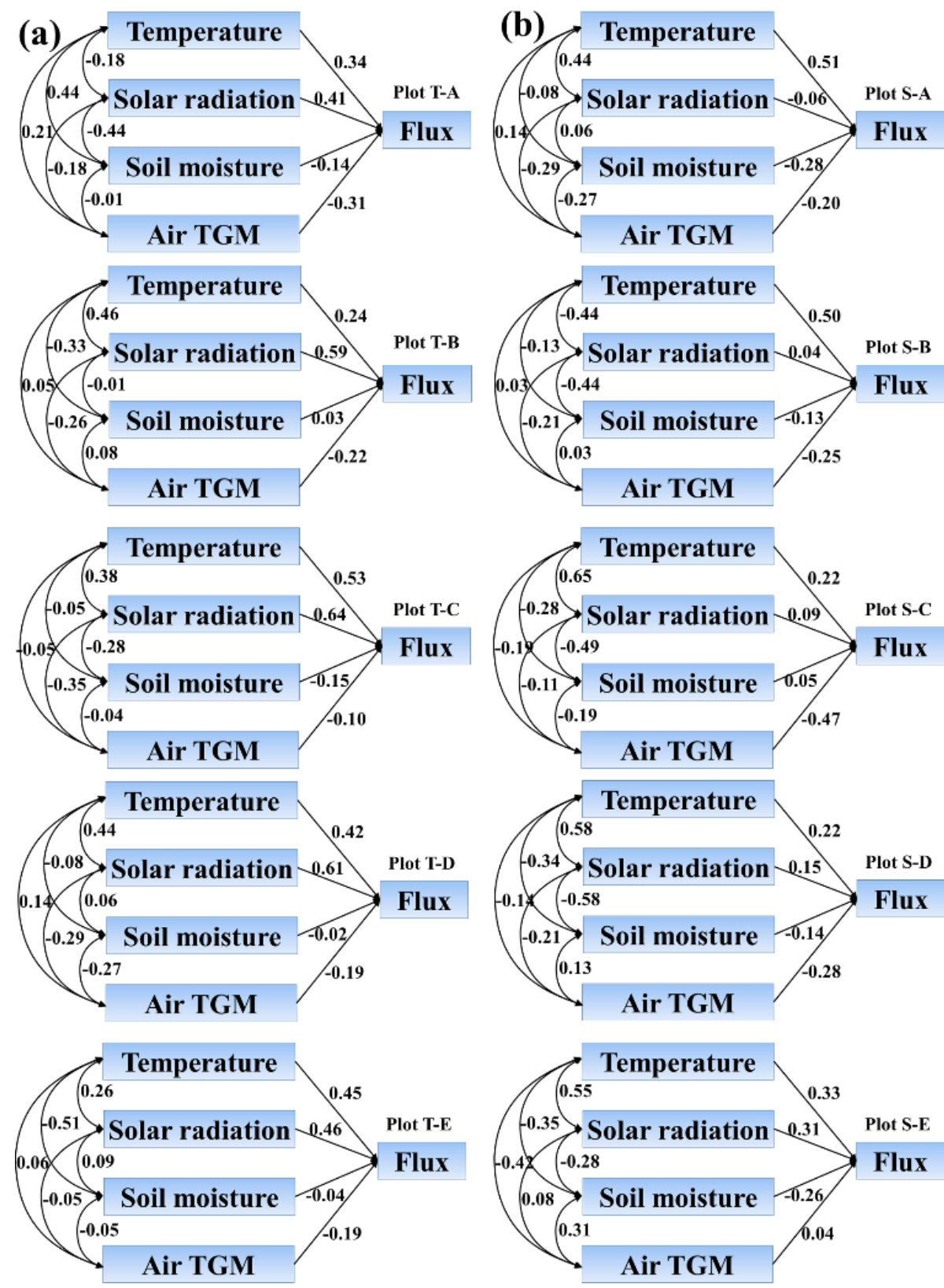

Figure 5. Interplays of environmental factors on the air-soil TGM exchange flux, obtained by structural equation model (SEM), in the temperate (a) and subtropical (b) forests.

Diurnal variations in soil-air TGM fluxes were measured in plot S-A at the subtropical forest (Fig. 8) and in plot T-D at the temperate forest (Fig. 9). Soil TGM fluxes were well correlated with soil and air temperature ( $p<0.01$ for all) and were highly dependent on solar radiation in spring, summer and autumn $(p<0.01$ for all) but not in winter $(p>0.05)$, which is similar to seasonal patterns from other studies (Howard and Edwards, 2018; Osterwalder et al., 2018; Johnson et al., 2003). Solar radiation has been shown to promote a photochemical reduction in soil-bound $\mathrm{Hg}$ and enrich $\mathrm{Hg}(0)$ in soil pore gas. This reaction is kinetically enhanced at higher temperatures (Eckley et al., 2015; Lin et al., 2010; Zhang et al., 2001). Compared to the other three seasons, the relatively low soil temperature $\left(5.95^{\circ} \mathrm{C}\right.$ at the subtropical forest and $-5.66^{\circ} \mathrm{C}$ at the temperate forest) may have limited the relationship between the soil TGM flux and solar radiation during the winter season. 

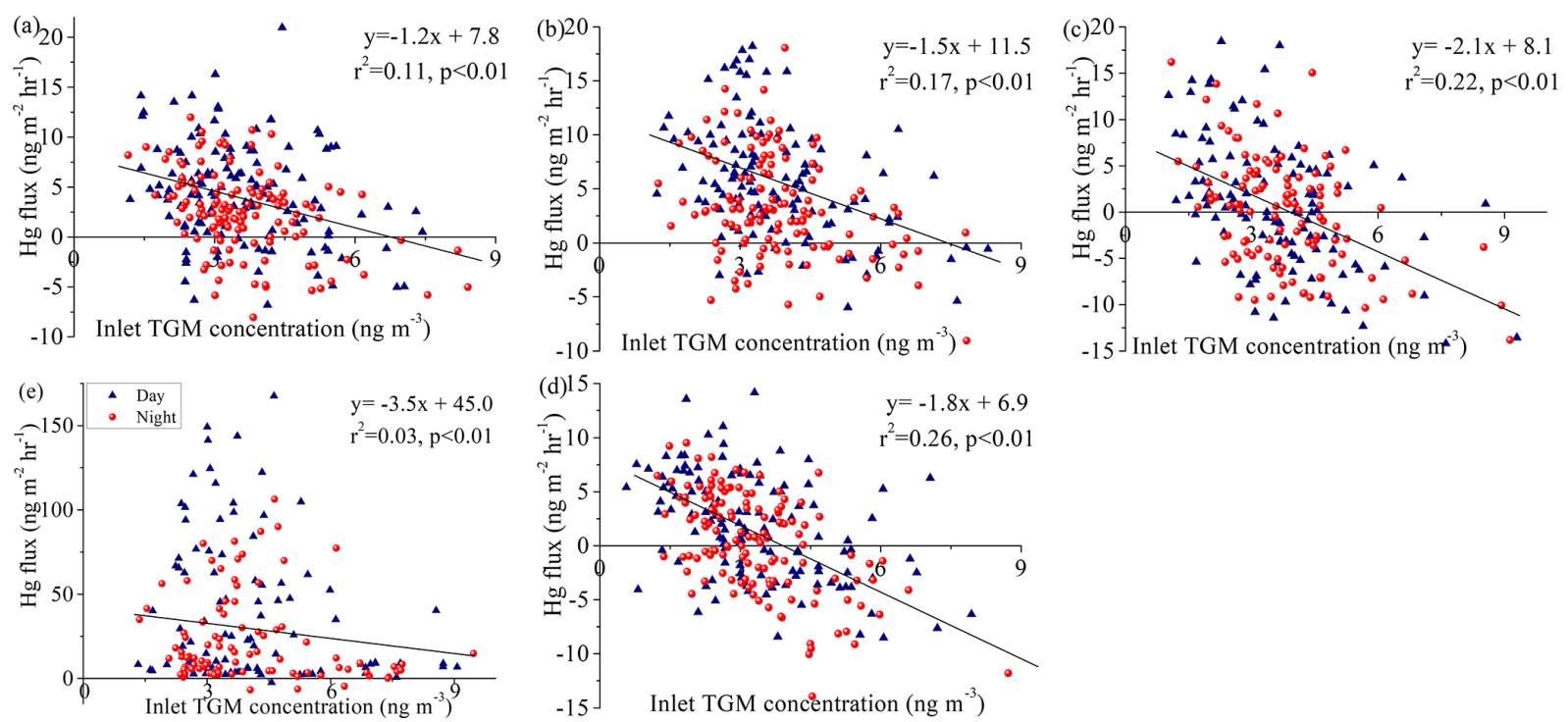

Figure 6. Correlation between the air TGM concentration and air-surface Hg flux measured in the daytime and nighttime over four seasons for Masson pine forest plots (a, b) and wetland (c), evergreen broad-leaved forest (d) and open field (e) plots in a subtropical forest.
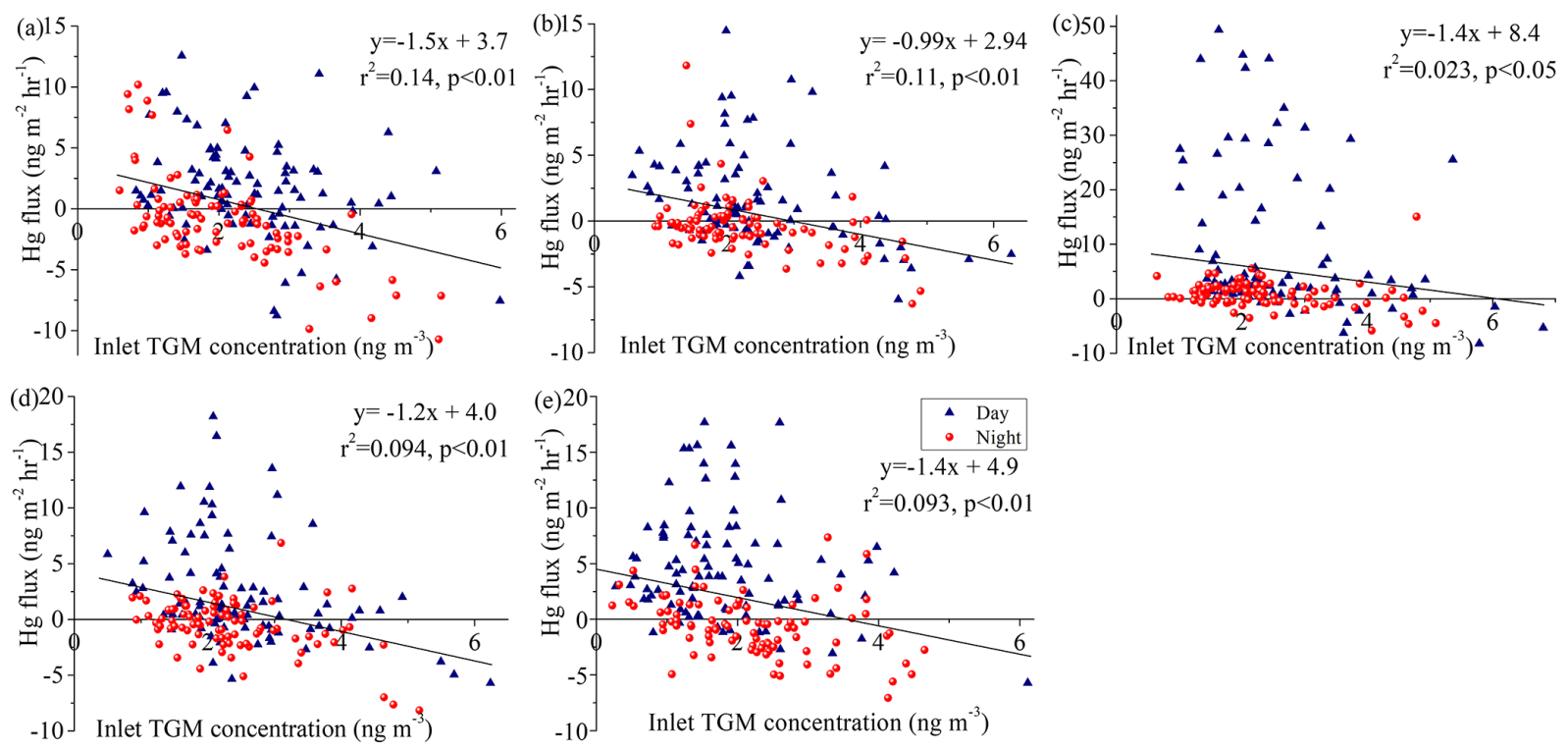

Figure 7. Correlation between the air TGM concentration and air-surface Hg flux measured in daytime and nighttime over four seasons for the five plots at a Chinese pine forest (a) and larch forest (b), wetland (c), mixed broad-leaved forest (d) and open field (e) plots in a temperate forest.

\section{Conclusions and study implications}

Prior to undertaking these measurements of $\mathrm{Hg}$ air-surface exchange flux, no direct measurements of $\mathrm{Hg}$ exchange flux were available for background landscapes in northern China. Our detailed direct observations have important implications for the role of forests in global and regional $\mathrm{Hg}$ cycles. Through multiplot measurements over 130 and $96 \mathrm{~d}$ at the subtropical and temperate forests in China, we were able to reduce the uncertainty in soil-atmosphere TGM fluxes at the catchment scale and improve our understanding of how landscape attributes contribute to variability in soil $\mathrm{Hg}$ evasion. It is inferred that forest soils acts as net TGM sources to the atmosphere. Strong correlations were evident between the soil $\mathrm{Hg}$ flux and environmental variables in some plots, such as solar radiation, temperature, soil moisture and air TGM concentrations.

The compensation points were determined for background forest soils from full-scale field data showing area-weighted values of 6.82 and $3.42 \mathrm{ng} \mathrm{m}^{-3}$ for the entire subtropical and 

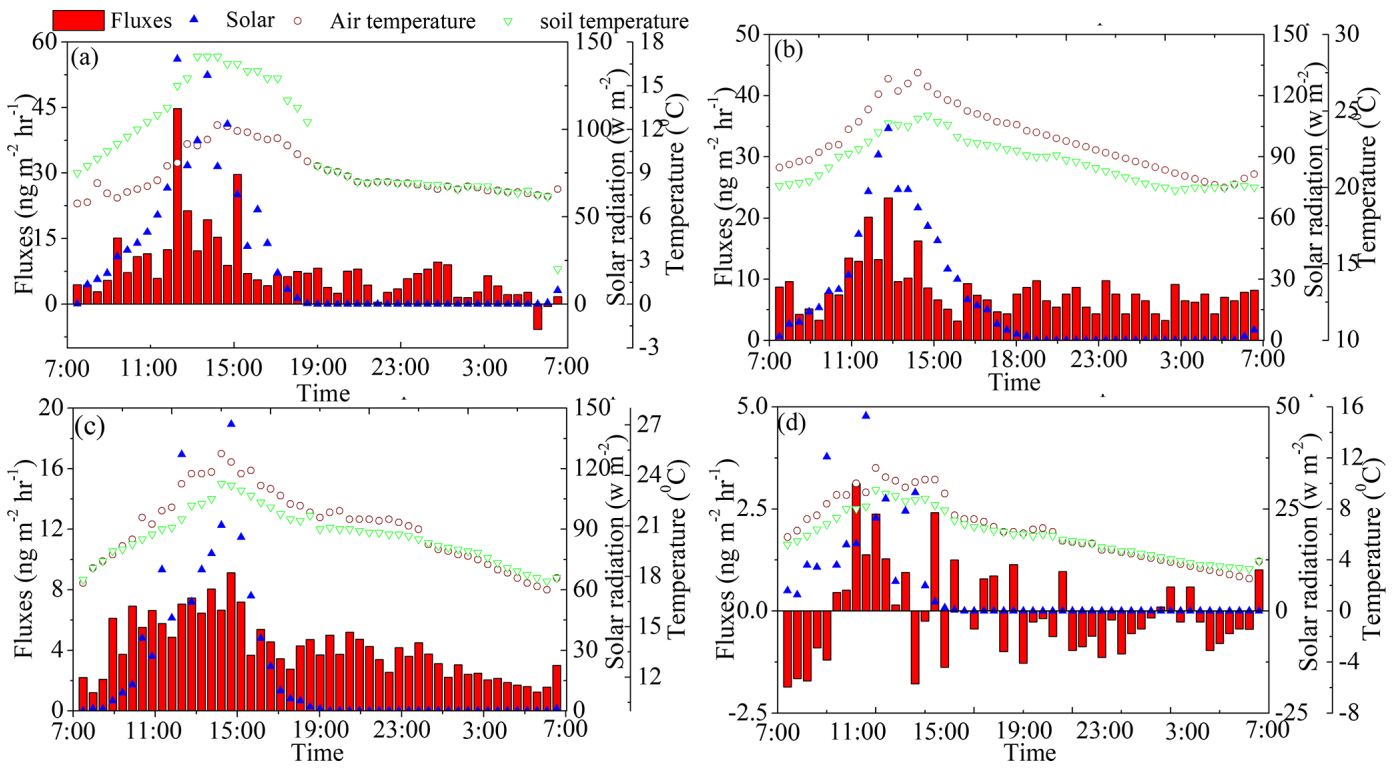

Figure 8. Diurnal patterns of soil $\mathrm{Hg}$ fluxes with meteorological parameters in spring (a), summer (b), autumn (c) and winter (d) in the coniferous forest of a subtropical forest.
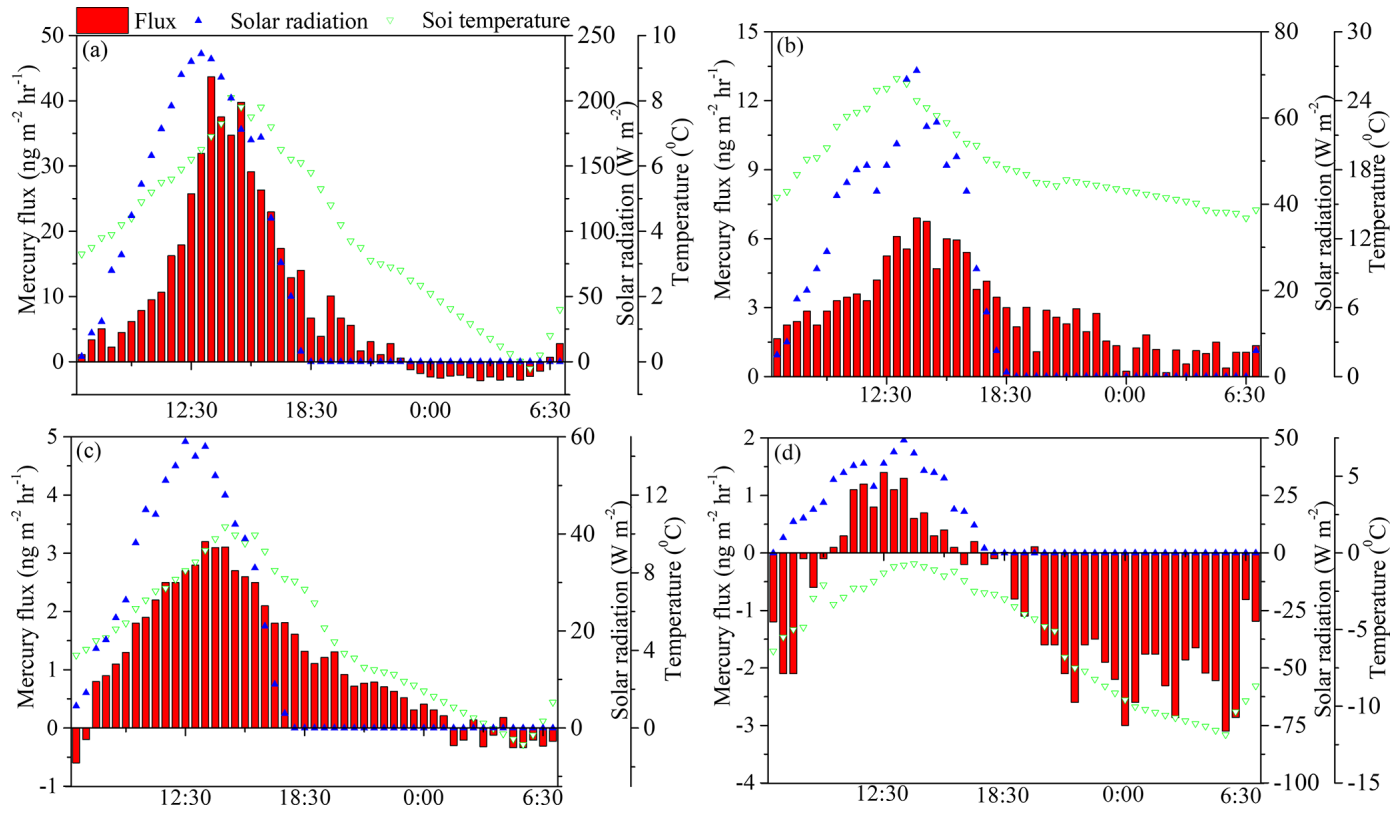

Figure 9. Diurnal patterns of soil Hg fluxes with meteorological parameters in spring (a), summer (b), autumn (c) and winter (d) in the deciduous broad-leaved forest of a temperate forest.

temperate catchments, respectively. The values of compensation indicate that the atmospheric TGM concentration can play a critical role in limiting TGM fluxes between the forest floor and atmosphere. Future studies need to focus on forest soils as an increasingly important source of $\mathrm{Hg}$ to the atmosphere because of recent declines in anthropogenic $\mathrm{Hg}$ emissions and TGM concentrations (Liu et al., 2019). Moreover, TGM re-emissions are partially derived from legacy $\mathrm{Hg}$ stored in surface soils. A recent study using models simulating the dynamics of the subtropical forest landscape under climate change, harvesting and land use disturbances in southern China showed that coniferous forest area increased by approximately 3.7 times compared to broad-leaved forest area (Wu et al., 2019). In the temperate forest, climatic changes in northern China are expected to cause coniferous stands to transition to deciduous forests over the next 
100 years (Ma et al., 2014). Climate change and land use disturbances may increase the compensation points in both temperate and subtropical forests and, therefore, increase the emissions of legacy $\mathrm{Hg}$ from terrestrial soils to the atmosphere. Some studies have emphasized that climate and land use change will potentially enhance deposition of $\mathrm{Hg}$ to forested landscapes (Haynes et al., 2017; Richardson and Friedland, 2015; Li et al., 2020); however, our study suggests that legacy $\mathrm{Hg}$ in forest soils could be emitted back to atmosphere, offsetting enhanced atmospheric $\mathrm{Hg}$ deposition. Better understanding of the response of $\mathrm{Hg}$ emissions from forest soils to climate and land use change is an important topic for future research.

Data availability. The data will be made available upon request to the corresponding author.

Supplement. The supplement related to this article is available online at: https://doi.org/10.5194/acp-20-16117-2020-supplement.

Author contributions. $\mathrm{ZW}$ and $\mathrm{XZ}$ conceived the experiment. JZ conducted the measurements. JZ wrote the paper with input from CTD, CL and ZW. All authors reviewed the paper.

Competing interests. The authors declare that they have no conflict of interest.

Acknowledgements. This work was funded by the Second Tibetan Plateau Scientific Expedition and Research Program (STEP; grant no. 2019QZKK0307), the Natural Science Foundation of China (grant nos. 42077345 and 42077381) the National 973 Program of China (grant no. 2013CB430002) and the National Key Research and Development Program of China (grant no. 2017YFC0210106). The authors would like to thank Mingquan Zou and the Beijing Forest Ecosystem Research Station, Chinese Academy of Sciences, for the help with our sampling and for providing the meteorological data.

Financial support. This research has been supported by the Second Tibetan Plateau Scientific Expedition and Research Program (STEP; grant no. 2019QZKK0307), the Natural Science Foundation of China (grant nos. 42077345 and 42077381), the National 973 Program of China (grant no. 2013CB430002) and the National Key Research and Development Program of China (grant no. 2017YFC0210106).

Review statement. This paper was edited by Ralf Ebinghaus and reviewed by two anonymous referees.

\section{References}

Agnan, Y., Le, D. T., Moore, C., Edwards, G., and Obrist, D.: New constraints on terrestrial surface-atmosphere fluxes of gaseous elemental mercury using a global database, Environ. Sci. Techol., 50, 507-524, https://doi.org/10.1021/acs.est.5b04013, 2016.

Angot, H., Dastoor, A., De Simone, F., Gårdfeldt, K., Gencarelli, C. N., Hedgecock, I. M., Langer, S., Magand, O., Mastromonaco, M. N., Nordstrøm, C., Pfaffhuber, K. A., Pirrone, N., Ryjkov, A., Selin, N. E., Skov, H., Song, S., Sprovieri, F., Steffen, A., Toyota, K., Travnikov, O., Yang, X., and Dommergue, A.: Chemical cycling and deposition of atmospheric mercury in polar regions: review of recent measurements and comparison with models, Atmos. Chem. Phys., 16, 10735-10763, https://doi.org/10.5194/acp-16-10735-2016, 2016.

Breuer, L., Kiese, R., and Butterbachbahl, K.: Temperature and moisture effects on nitrification rates in tropical rain-forest soils, Soil Sci. Soc. Am. J., 66, 399-402, 2002.

Carpi, A., Fostier, A. H., Orta, O. R., dos Santos, J. C., and Gittings, M.: Gaseous mercury emissions from soil following forest loss and land use changes: Field experiments in the United States and Brazil, Atmos. Environ., 96, 423-429, https://doi.org/10.1016/j.atmosenv.2014.08.004, 2014.

Chen, Y., Yin, Y., Shi, J., Liu, G., Hu, L., Liu, J., Cai, Y., and Jiang, G.: Analytical methods, formation, and dissolution of cinnabar and its impact on environmental cycle of mercury, Critical Reviews in Environmental Science and Technology, 47, 24152447, https://doi.org/10.1080/10643389.2018.1429764, 2017.

Cheng, Z., Tang, Y., Li, E., Wu, Q., Wang, L., Liu, K., Wang, S., Huang, Y., and Duan, L.: Mercury accumulation in soil from atmospheric deposition in temperate steppe of Inner Mongolia, China, Environ. Poll., 258, 113692, https://doi.org/10.1016/j.envpol.2019.113692, 2020.

Choi, H.-D. and Holsen, T. M.: Gaseous mercury emissions from unsterilized and sterilized soils: The effect of temperature and UV radiation, Environ. Poll., 157, 1673-1678, https://doi.org/10.1016/j.envpol.2008.12.014, 2009a.

Choi, H. D. and Holsen, T. M.: Gaseous mercury fluxes from the forest floor of the Adirondacks, Environ. Pollut., 157, 592-600, 2009b.

Du, B., Zhou, J., Zhou, L., Fan, X., and Zhou, J.: Mercury distribution in the foliage and soil profiles of a subtropical forest: Process for mercury retention in soils, J. Geochem. Explor., 205, 106337, https://doi.org/10.1016/j.gexplo.2019.106337, 2019.

Durnford, D. and Dastoor, A.: The behavior of mercury in the cryosphere: A review of what we know from observations, J. Geophys. Res.-Atmos., 116, D06305, https://doi.org/10.1029/2010jd014809, 2011.

Eckley, C. S., Gustin, M., Lin, C. J., Li, X., and Miller, M. B.: The influence of dynamic chamber design and operating parameters on calculated surface-to-air mercury fluxes, Atmos. Environ., 44, 194-203, https://doi.org/10.1016/j.atmosenv.2009.10.013, 2010.

Eckley, C. S., Blanchard, P., Mclennan, D., Mintz, R., and Sekela, M.: Soil-air mercury flux near a large industrial emission source before and after closure (Flin Flon, Manitoba, Canada), Environ. Sci. Technol., 49, 9750-9757, 2015.

Fang, J., Liu, G., Zhu, B., Wang, X., and Liu, S.: Carbon budgets of three temperate forest ecosystems in Dongling Mt., Beijing, China, Sci. China Ser. D, 50, 92-101, https://doi.org/10.1007/s11430-007-2031-3, 2007. 
FAO: UNESCO soil map of the world, revised legend, in: World Res. Rep., FAO, Rome, 138, 1988.

Fraser, A., Dastoor, A., and Ryjkov, A.: How important is biomass burning in Canada to mercury contamination?, Atmos. Chem. Phys., 18, 7263-7286, https://doi.org/10.5194/acp18-7263-2018, 2018.

$\mathrm{Fu}, \mathrm{X}$., Feng, X., and Wang, S.: Exchange fluxes of $\mathrm{Hg}$ between surfaces and atmosphere in the eastern flank of Mount Gongga, Sichuan province, southwestern China, J. Geophys. Res.-Atmos., 113, 253-270, 2008.

Gao, Y., Wang, Z., Zhang, X., and Wang, C.: Observation and estimation of mercury exchange fluxes from soil under different crop cultivars and planting densities in North China Plain, Environ. Pollut., 259, 113833, https://doi.org/10.1016/j.envpol.2019.113833, 2020.

Gustin, M. S.: Are mercury emissions from geologic sources significant? A status report, Sci. Total Environ., 304, 153-167, https://doi.org/10.1016/S0048-9697(02)00565-X, 2003.

Gustin, M. S. and Stamenkovic, J.: Effect of watering and soil moisture on mercury emissions from soils, Biogeochemistry, 76, 215$232,2005$.

Gustin, M. S., Engle, M., Ericksen, J., Lyman, S., Stamenkovic, J., and Xin, M.: Mercury exchange between the atmosphere and low mercury containing substrates, Appl. Geochem., 21, 1913-1923, 2006.

Hararuk, O., Obrist, D., and Luo, Y.: Modelling the sensitivity of soil mercury storage to climate-induced changes in soil carbon pools, Biogeosciences, 10, 2393-2407, https://doi.org/10.5194/bg-10-2393-2013, 2013.

Hartman, J. S., Weisberg, P. J., Pillai, R., Ericksen, J. A., Kuiken, T., Lindberg, S. E., Zhang, H., Rytuba, J. J., and Gustin, M. S.: Application of a rule-based model to estimate mercury exchange for three background biomes in the continental United States, Environ. Sci. Technol., 43, 4989-4994, https://doi.org/10.1021/es900075q, 2009.

Haynes, K. M., Kane, E. S., Potvin, L., Lilleskov, E. A., Kolka, R. K., and Mitchell, C. P. J.: Gaseous mercury fluxes in peatlands and the potential influence of climate change, Atmos. Environ., 154, 247-259, https://doi.org/10.1016/j.atmosenv.2017.01.049, 2017.

Hou, H. Y.: Vegetation Map of P.R. China (1:4,000,000), Map Press of China, Beijing, 1982.

Howard, D. and Edwards, G. C.: Mercury fluxes over an Australian alpine grassland and observation of nocturnal atmospheric mercury depletion events, Atmos. Chem. Phys., 18, 129-142, https://doi.org/10.5194/acp-18-129-2018, 2018.

Johnson, D. W., Benesch, J. A., Gustin, M. S., Schorran, D. S., Lindberg, S. E., and Coleman, J. S.: Experimental evidence against diffusion control of $\mathrm{Hg}$ evasion from soils, Sci. Total Environ., 304, 175-184, https://doi.org/10.1016/S0048-9697(02)00567-3, 2003.

Kamp, J., Skov, H., Jensen, B., and Sørensen, L. L.: Fluxes of gaseous elemental mercury (GEM) in the High Arctic during atmospheric mercury depletion events (AMDEs), Atmos. Chem. Phys., 18, 6923-6938, https://doi.org/10.5194/acp-186923-2018, 2018.

Kiese, R. and Butterbach-Bahl, K.: $\mathrm{N}_{2} \mathrm{O}$ and $\mathrm{CO}_{2}$ emissions from three different tropical forest sites in the wet tropics of Queensland, Australia, Soil Biol. Biochem., 34, 975-987, 2002.
Kocman, D. and Horvat, M.: A laboratory based experimental study of mercury emission from contaminated soils in the River Idrijca catchment, Atmos. Chem. Phys., 10, 1417-1426, https://doi.org/10.5194/acp-10-1417-2010, 2010.

Kumari, A., Kumar, B., Manzoor, S., and Kulshrestha, U.: Status of Atmospheric Mercury Research in South Asia: A Review, Aerosol Air Qual. Res., 15, 1092-1109, https://doi.org/10.4209/aaqr.2014.05.0098, 2015.

Kuss, J., Krüger, S., Ruickoldt, J., and Wlost, K.-P.: High-resolution measurements of elemental mercury in surface water for an improved quantitative understanding of the Baltic Sea as a source of atmospheric mercury, Atmos. Chem. Phys., 18, 4361-4376, https://doi.org/10.5194/acp-18-4361-2018, 2018.

Li, F., Ma, C., and Zhang, P.: Mercury Deposition, Climate Change and Anthropogenic Activities: A Review, Front. Earth Sci., 8, 316, https://doi.org/10.3389/feart.2020.00316, 2020.

Lin, C. J., Gustin, M. S., Singhasuk, P., Eckley, C., and Miller, M.: Empirical models for estimating mercury flux from soils, Environ. Sci. Technol., 44, 8522-8528, 2010.

Lin, H., Tong, Y., Yin, X., Zhang, Q., Zhang, H., Zhang, H., Chen, L., Kang, S., Zhang, W., Schauer, J., de Foy, B., Bu, X., and Wang, X.: First measurement of atmospheric mercury species in Qomolangma Natural Nature Preserve, Tibetan Plateau, and evidence oftransboundary pollutant invasion, Atmos. Chem. Phys., 19, 1373-1391, https://doi.org/10.5194/acp19-1373-2019, 2019.

Liu, K., Wu, Q., Wang, L., Wang, S., Liu, T., Ding, D., Tang, Y., Li, G., Tian, H., Duan, L., Wang, X., Fu, X., Feng, X., and Hao, J.: Measure-specific effectiveness of air pollution control on China's atmospheric mercury concentration and deposition during 2013-2017, Environ. Sci. Technol., 53, 8938-8946, https://doi.org/10.1021/acs.est.9b02428, 2019.

Luo, Y.: Mercury input, output and transport in forest ecosystems in southern China, $\mathrm{PhD}$ thesis, Tsinghua University, Beijing, China, 1-112, 2015.

Ly Sy Phu, N., Zhang, L., Lin, D.-W., Lin, N.-H., and Sheu, G.-R.: Eight-year dry deposition of atmospheric mercury to a tropical high mountain background site downwind of the East Asian continent, Environ. Pollut., 255, 113128, https://doi.org/10.1016/j.envpol.2019.113128, 2019.

Ma, J., Hu, Y., Bu, R., Chang, Y., Deng, H., and Qin, Q.: Predicting Impacts of Climate Change on the Aboveground Carbon Sequestration Rate of a Temperate Forest in Northeastern China, Plos One, 9, e96157, https://doi.org/10.1371/journal.pone.0096157, 2014.

Ma, M., Wang, D., Sun, R., Shen, Y., and Huang, L.: Gaseous mercury emissions from subtropical forested and open field soils in a national nature reserve, southwest China, Atmos. Environ., 64, 116-123, 2013.

Ma, M., Sun, T., Du, H., and Wang, D.: A Two-Year Study on Mercury Fluxes from the Soil under Different Vegetation Cover in a Subtropical Region, South China, Atmosphere-Basel, 9, 30, https://doi.org/10.3390/atmos9010030, 2018.

Manca, G., Ammoscato, I., Esposito, G., Ianniello, A., Nardino, M., and Sprovieri, F.: Dynamics of snow-air mercury exchange at Ny Ålesund during springtime 2011, E3S Web of Conferences, EDP Sciences, 1, 03010, https://doi.org/10.1051/e3sconf/20130103010, 2013. 
Maxwell, J. A., Holsen, T. M., and Mondal, S.: Gaseous elemental mercury (GEM) emissions from snow surfaces in northern New York, Plos One, 8, e69342, https://doi.org/10.1371/journal.pone.0069342, 2013.

Mo, F., Li, X., He, S., and Wang, X.: Evaluation of soil and water conservation capacity of different forest types in Dongling Mountain, Shengtai Xuebao, Acta Ecologica Sinica, 31, 50095016, 2011.

Nagati, M., Roy, M., DesRochers, A., Bergeron, Y., and Gardes, M.: Importance of soil, stand, and mycorrhizal fungi inabiesbalsameaestablishment in the boreal forest, Forests, 11, 815, https://doi.org/10.3390/f11080815, 2020.

Obrist, D.: Mercury distribution across 14 U.S. forests. Part II: Patterns of methyl mercury concentrations and areal mass of total and methyl mercury, Environ. Sci. Technol., 46, 5921-5930, https://doi.org/10.1021/es2045579, 2012.

Obrist, D., Faïn, X., and Berger, C.: Gaseous elemental mercury emissions and $\mathrm{CO}_{2}$ respiration rates in terrestrial soils under controlled aerobic and anaerobic laboratory conditions, Sci. Total Environ., 408, 1691-1700, 2010.

Obrist, D., Pokharel, A. K., and Moore, C.: Vertical profile measurements of soil air suggest immobilization of gaseous elemental mercury in mineral soil, Environ. Sci. Technol., 48, 2242-2252, https://doi.org/10.1021/es4048297, 2014.

Obrist, D., Kirk, J. L., Zhang, L., Sunderland, E. M., Jiskra, M., and Selin, N. E.: A review of global environmental mercury processes in response to human and natural perturbations: Changes of emissions, climate, and land use, Ambio, 47, 116140, https://doi.org/10.1007/s13280-017-1004-9, 2018.

O’Connor, D., Hou, D., Ok, Y. S., Mulder, J., Duan, L., Wu, Q., Wang, S., Tack, F. M. G., and Rinklebe, J.: Mercury speciation, transformation, and transportation in soils, atmospheric flux, and implications for risk management: A critical review, Environ. Int., 126, 747-761, https://doi.org/10.1016/j.envint.2019.03.019, 2019.

Olson, C., Jiskra, M., Biester, H., Chow, J., and Obrist, D.: Mercury in Active-Layer Tundra Soils of Alaska: Concentrations, Pools, Origins, and Spatial Distribution, Global Biogeochem. Cy., 32, 1058-1073, https://doi.org/10.1029/2017gb005840, 2018.

Osterwalder, S., Sommar, J., Akerblom, S., Jocher, G., Fritsche, J., Nilsson, M. B., Bishop, K., and Alewell, C.: Comparative study of elemental mercury flux measurement techniques over a Fennoscandian boreal peatland, Atmos. Environ., 172, 16-25, https://doi.org/10.1016/j.atmosenv.2017.10.025, 2018.

Osterwalder, S., Huang, J.-H., Shetaya, W. H., Agnan, Y., Frossard, A., Frey, B., Alewell, C., Kretzschmar, R., Biester, H., and Obrist, D.: Mercury emission from industrially contaminated soils in relation to chemical, microbial, and meteorological factors, Environ. Pollut., 250, 944-952, https://doi.org/10.1016/j.envpol.2019.03.093, 2019.

Outridge, P. M., Mason, R. P., Wang, F., Guerrero, S., and Heimburger-Boavida, L. E.: Updated global and oceanic mercury budgets for the united nations global mercury assessment 2018, Environ. Sci. Technol., 52, 11466-11477, https://doi.org/10.1021/acs.est.8b01246, 2018.

Pan, L., Lin, C.-J., Carmichael, G. R., Streets, D. G., Tang, Y., Woo, J.-H., Shetty, S. K., Chu, H.-W., Ho, T. C., Friedli, H. R., and Feng, X.: Study of atmospheric mercury budget in East Asia us- ing STEM-Hg modeling system, Sci. Total Environ., 408, 32773291, https://doi.org/10.1016/j.scitotenv.2010.04.039, 2010.

Pannu, R., Siciliano, S. D., and O'Driscoll, N. J.: Quantifying the effects of soil temperature, moisture and sterilization on elemental mercury formation in boreal soils, Environ. Poll., 193, 138-146, https://doi.org/10.1016/j.envpol.2014.06.023, 2014.

Peleg, M., Tas, E., Matveev, V., Obrist, D., Moore, C. W., Gabay, M., and Luria, M.: Observational evidence for involvement of nitrate radicals in nighttime oxidation of mercury, Environ. Sci. Technol., 49, 14008-14018, https://doi.org/10.1021/acs.est.5b03894, 2015.

Perez-Rodriguez, M., Biester, H., Aboal, J. R., Toro, M., and Martinez Cortizas, A.: Thawing of snow and ice caused extraordinary high and fast mercury fluxes to lake sediments in Antarctica, Geochim. Cosmochim. Ac., 248, 109-122, https://doi.org/10.1016/j.gca.2019.01.009, 2019.

Richardson, J. B. and Friedland, A. J.: Mercury in coniferous and deciduous upland forests in northern New England, USA: implications of climate change, Biogeosciences, 12, 6737-6749, https://doi.org/10.5194/bg-12-6737-2015, 2015.

Risch, M. R., DeWild, J. F., Gay, D. A., Zhang, L., Boyer, E. W., and Krabbenhoft, D. P.: Atmospheric mercury deposition to forests in the eastern USA, Environ. Poll., 228, 8-18, https://doi.org/10.1016/j.envpol.2017.05.004, 2017.

Slemr, F., Weigelt, A., Ebinghaus, R., Bieser, J., Brenninkmeijer, C. A. M., Rauthe-Schöch, A., Hermann, M., Martinsson, B. G., van Velthoven, P., Bönisch, H., Neumaier, M., Zahn, A., and Ziereis, H.: Mercury distribution in the upper troposphere and lowermost stratosphere according to measurements by the IAGOS-CARIBIC observatory: 2014-2016, Atmos. Chem. Phys., 18, 12329-12343, https://doi.org/10.5194/acp-18-123292018, 2018.

Sørbotten, L.-E.: Hill slope unsaturated flowpaths and soil moisture variability in a forested catchment in Southwest China, MSc thesis, Department of Plant and Environmental Sciences, University of Life Sciences, Oslo, Norway, 2011.

Spolaor, A., Barbaro, E., Cappelletti, D., Turetta, C., Mazzola, M., Giardi, F., Björkman, M. P., Lucchetta, F., Dallo, F., Pfaffhuber, K. A., Angot, H., Dommergue, A., Maturilli, M., SaizLopez, A., Barbante, C., and Cairns, W. R. L.: Diurnal cycle of iodine, bromine, and mercury concentrations in Svalbard surface snow, Atmos. Chem. Phys., 19, 13325-13339, https://doi.org/10.5194/acp-19-13325-2019, 2019.

St Louis, V. L., Graydon, J. A., Lehnherr, I., Amos, H. M., Sunderland, E. M., St Pierre, K. A., Emmerton, C. A., Sandilands, K., Tate, M., Steffen, A., and Humphreys, E. R.: Atmospheric Concentrations and Wet/Dry Loadings of Mercury at the Remote Experimental Lakes Area, Northwestern Ontario, Canada, Environ. Sci. Technol., 53, 8017-8026, https://doi.org/10.1021/acs.est.9b01338, 2019.

Sun, T., Ma, M., Wang, X., Wang, Y., Du, H., Xiang, Y., Xu, Q., Xie, Q., and Wang, D.: Mercury transport, transformation and mass balance on a perspective of hydrological processes in a subtropical forest of China, Environ. Poll., 254, 113065, https://doi.org/10.1016/j.envpol.2019.113065, 2019.

Teixeira, D. C., Lacerda, L. D., and Silva-Filho, E. V.: Foliar mercury content from tropical trees and its correlation with physiological parameters in situ, Environ. Pollut., 242, 1050-1057, https://doi.org/10.1016/j.envpol.2018.07.120, 2018. 
Wang, Q., Luo, Y., Du, B., Ye, Z., and Duan, L.: Influencing factors of mercury emission flux from forest soil at tieshanping, chongqing, Environ. Sci., 35, 1922-1927, 2014 (in Chinese with English abstract).

Wang, S., Feng, X., Qiu, G., Fu, X., and Wei, Z.: Characteristics of mercury exchange flux between soil and air in the heavily air-polluted area, eastern Guizhou, China, Atmos. Environ., 41, 5584-5594, 2007.

Wang, X., Bao, Z., Lin, C.-J., Yuan, W., and Feng, X.: Assessment of global mercury deposition through litterfall, Environ. Sci. Technol., 50, 8548-8557, 2016.

Wang, X., Lin, C.-J., Feng, X., Yuan, W., Fu, X., Zhang, H., Wu, Q., and Wang, S.: Assessment of regional mercury deposition and emission outflow in mainland China, J. Geophys. Res.-Atmos., 123, 9868-9890, https://doi.org/10.1029/2018jd028350, 2018.

Wang, Z., Zhang, X., Xiao, J., Zhijia, C., and Yu, P.: Mercury fluxes and pools in three subtropical forested catchments, southwest China, Environ. Poll., 157, 801-808, https://doi.org/10.1016/j.envpol.2008.11.018, 2009.

Wang, Z. H., Zhang, G., Wang, Y., Zhao, Y. X., and Sun, X. J.: Research on mercury flux between snow and air under the condition of seasonal snow cover environment, J. Agro-Environ. Sci., 32, 601-606, 2013.

Wright, L. P., Zhang, L., and Marsik, F. J.: Overview of mercury dry deposition, litterfall, and throughfall studies, Atmos. Chem. Phys., 16, 13399-13416, https://doi.org/10.5194/acp-16-133992016, 2016.

Wu, Z., Dai, E., Wu, Z., and Lin, M.: Future forest dynamics under climate change, land use change, and harvest in subtropical forests in Southern China, Landscape Ecol., 34, 843-863, https://doi.org/10.1007/s10980-019-00809-8, 2019.

Xin, M. and Gustin, M. S.: Gaseous elemental mercury exchange with low mercury containing soils: Investigation of controlling factors, Appl. Geochem., 22, 1451-1466, 2007.

Yu, Q., Luo, Y., Xu, G., Wu, Q., Wang, S., Hao, J., and Duan, L.: Subtropical forests act as mercury sinks but as net sources of gaseous elemental mercury in south China, Environ. Sci. Technol., 54, 2772-2779, https://doi.org/10.1021/acs.est.9b06715, 2020.

Yuan, W., Sommar, J., Lin, C.-J., Wang, X., Li, K., Liu, Y., Zhang, H., Lu, Z., Wu, C., and Feng, X.: Stable Isotope Evidence Shows Re-emission of Elemental Mercury Vapor Occurring after Reductive Loss from Foliage, Environ. Sci. Technol., 53, 651-660, https://doi.org/10.1021/acs.est.8b04865, 2019a.

Yuan, W., Wang, X., Lin, C.-J., Sommar, J., Lu, Z., and Feng, X.: Process factors driving dynamic exchange of elemental mercury vapor over soil in broadleaf forest ecosystems, Atmos. Environ., 219, 117047, https://doi.org/10.1016/j.atmosenv.2019.117047, 2019b.

Zarate-Valdez, J. L., Zasoski, R. J., and Lauchli, A.: Short-term effects of moisture content on soil solution $\mathrm{pH}$ and soil Eh, Soil Sci., 171, 423-431, 2006.

Zhang, G., Wang, N., Ai, J.-C., Zhang, L., Yang, J., and Liu, Z.-Q.: Characteristics of mercury exchange flux between soil and atmosphere under the snow retention and snow melting control, Huanjing Kexue, Chinese Journal of Environmental Science website, 34, 468-475, 2013.

Zhang, H., Lindberg, S. E., Marsik, F. J., and Keeler, G. J.: Mercury air/surface exchange kinetics of background soils of the tahqua- menon river watershed in the Michigan Upper Peninsula, Water Air Soil Pollut., 126, 151-169, 2001.

Zhang, H., Lindberg, S. E., Barnett, M. O., Vette, A. F., and Gustin, M. S.: Dynamic flux chamber measurement of gaseous mercury emission fluxes over soils. Part 1: simulation of gaseous mercury emissions from soils using a two-resistance exchange interface model, Atmos. Environ., 36, 835-846, 2002.

Zhang, H., Nizzetto, L., Feng, X., Borga, K., Sommar, J., Fu, X., Zhang, H., Zhang, G., and Larssen, T.: Assessing Air-Surface Exchange and Fate of Mercury in a Subtropical Forest Using a Novel Passive Exchange-Meter Device, Environ. Sci. Technol., 53, 4869-4879, https://doi.org/10.1021/acs.est.8b06343, 2019a.

Zhang, L., Zhou, P., Cao, S., and Zhao, Y.: Atmospheric mercury deposition over the land surfaces and the associated uncertainties in observations and simulations: a critical review, Atmos. Chem. Phys., 19, 15587-15608, https://doi.org/10.5194/acp-19-155872019, 2019b.

Zhang, Q., Huang, J., Wang, F., Mark, L., Xu, J., Armstrong, D., Li, C., Zhang, Y., and Kang, S.: Mercury distribution and deposition in glacier snow over western China, Environ. Sci. Technol., 46, 5404-5413, https://doi.org/10.1021/es300166x, 2012.

Zhou, J., Wang, Z., Zhang, X., and Chen, J.: Distribution and elevated soil pools of mercury in an acidic subtropical forest of southwestern China, Environ. Poll., 202, 187-195, https://doi.org/10.1016/j.envpol.2015.03.021, 2015.

Zhou, J., Wang, Z., Sun, T., Zhang, H., and Zhang, X.: Mercury in terrestrial forested systems with highly elevated mercury deposition in southwestern China: The risk to insects and potential release from wildfires, Environ. Poll., 212, 188-196, https://doi.org/10.1016/j.envpol.2016.01.003, 2016.

Zhou, J., Wang, Z., Zhang, X., and Gao, Y.: Mercury concentrations and pools in four adjacent coniferous and deciduous upland forests in Beijing, China, J. Geophys. Res-Biogeosci., 122, 1260-1274, 2017a.

Zhou, J., Wang, Z., Zhang, X., and Sun, T.: Investigation of factors affecting mercury emission from subtropical forest soil: A field controlled study in southwestern China, J. Geochem. Explor., 176, 128-135, https://doi.org/10.1016/j.gexplo.2015.10.007, $2017 b$.

Zhou, J., Wang, Z., and Zhang, X.: Deposition and fate of mercury in litterfall, litter, and soil in coniferous and broadleaved forests, J. Geophys. Res-Biogeo., 123, 2590-2603, https://doi.org/10.1029/2018jg004415, 2018.

Zhou, J., Du, B., Shang, L., Wang, Z., Cui, H., Fan, X., and Zhou, J.: Mercury fluxes, budgets, and pools in forest ecosystems of China: A review, Crit. Rev. Env. Sci. Technol., 50, 1411-1450, 2020a.

Zhou, J., Wang, Z., Zhang, X., and Driscoll, C. T.: Measurement of vertical distribution of gaseous elemental mercury concentration in soil pore air at subtropical and temperate forests, Environ. Sci. Technol., in review, 2020b.

Zhu, W., Lin, C.-J., Wang, X., Sommar, J., Fu, X., and Feng, X.: Global observations and modeling of atmosphere-surface exchange of elemental mercury: a critical review, Atmos. Chem. Phys., 16, 4451-4480, https://doi.org/10.5194/acp-164451-2016, 2016. 